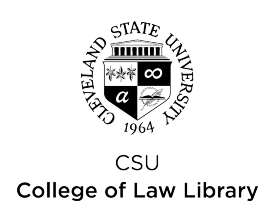

Cleveland State University

College of Law Library

\title{
EngagedScholarship@CSU
}

1986

\section{The Law/Politics Distinction, the French Conseil Constitutionnel, and the U.S. Supreme Court}

Michael H. Davis

Cleveland-Marshall College of Law, Cleveland State University, m.davis@csuohio.edu

Follow this and additional works at: https://engagedscholarship.csuohio.edu/fac_articles

Part of the Comparative and Foreign Law Commons, Courts Commons, Judges Commons, and the Jurisprudence Commons

How does access to this work benefit you? Let us know!

Original Citation

Michael Henry Davis, The Law/Politics Distinction, the French Conseil Constitutionnel, and the U.S.

Supreme Court, 34 American Journal of Comparative Law 45 (1986)

This Article is brought to you for free and open access by the Faculty Scholarship at EngagedScholarship@CSU. It has been accepted for inclusion in Law Faculty Articles and Essays by an authorized administrator of EngagedScholarship@CSU. For more information, please contact research.services@law.csuohio.edu. 


\section{HEINONLINE}

Citation: 34 Am. J. Comp. L. 451986

Content downloaded/printed from

HeinOnline (http://heinonline.org)

Thu Sep 27 15:51:58 2012

-- Your use of this HeinOnline PDF indicates your acceptance of HeinOnline's Terms and Conditions of the license agreement available at http://heinonline.org/HOL/License

-- The search text of this PDF is generated from uncorrected OCR text.

-- To obtain permission to use this article beyond the scope of your HeinOnline license, please use:

https://www.copyright.com/ccc/basicSearch.do?

\&operation $=$ go\&search Type $=0$

\&lastSearch $=$ simple\&all=on\&titleOrStdNo=0002-919X 


\section{The Law/Politics Distinction, the French Conseil Constitutionnel, and the U.S. Supreme Court}

A dispute burns across the landscape of French constitutional law regarding the juridical nature of the French constitutional "Supreme Court", the Conseil constitutionnel: is it a court? Both French and American scholars have claimed that, despite superficial similarities between the U.S. Supreme Court and the French Conseil constitutionnel," the American system of judicial review "can have no counterpart in the French system", 2 that French legal and political theory is inconsistent with an effective supreme court, that there is "no possibility" that the French and American systems could surmount this "major difference", ${ }^{3}$ and that the Conseil is simply not a "true court".4

The scholars furnish six fundamental reasons. 5 First, its membership is political and unprotected by life tenure. Second, its subject matter is substantially limited to proposed rather than existing legislation and, further, the scope of such review is limited to deciding only whether the legislature has intruded upon the executive, not reaching the substantive constitutional issues with which Americans are familiar. Third, matters brought before the Conseil are not contradicted; while there may be a controversy, its resolution never

MiChaEL H. DAvis is Associate Professor of Law, Cleveland-Marshall College of Law, Cleveland State University, Cleveland, Ohio. The author is indebted to the following people for their help, encouragement, patience, and generosity, for their examples that it is possible to bridge two cultures to the profit of both, and for the lesson therein that world peace can be both real and ideal: Prof. Arthur T. von Mehren, Prof. Andre Tunc, Prof. Xavier Blanc-Jouvan, and Prof. Louis Favoreu. The author also thanks his research assistant, John Oreh, and Prof. Favoreu's research assistant, Patrick Gaia, for their time and professionalism.

1. I will refer to the Conseil constitutionnel throughout this article as the Conseil, except when directly translating from French text into English. In those instances, I use the literal English equivalent, "Constitutional Council", or, where the French text so dictates, simply "Council". When referring to other French organs which may have confusingly similar labels, however, especially the Conseil d'Etat, I use the full title to distinguish them, unless, again, it appears within a translation from the French text in which case, if the context does not indicate to which organ the text refers, a bracketed addition completes the identification.

2. Tallon, "The Constitution and the Courts in France," 27 Am. J. Comp. L. 567, 575 (1979).

3. Id. at 575. See also text, infra at 58-60.

4. Von Mehren \& Gordley, The Civil Law System 121 (2nd ed., 1977).

5. See text, infra at 58-65 for detailed description of the Conseil. 
entails a "case" involving individual litigating parties. Fourth, its procedures are secretive, non-public, arguably nonjudicial, and do not offer any formal access-for individuals, groups, or the publicto the questions it considers. Fifth, its jurisdiction is ambiguous, sharing ultimate power with two other independent jurisdictions. Accordingly, the finality of its decisions is more theoretical than real. Sixth and finally, its institutional design seems nonjudicial, its textual constitutional source arising from a section separate from the judiciary, its historical roots being allied more with the legislature and executive than with the judiciary.

\section{ThE FrenCh ANTIPATHY TO JUdicial HIERARCHY}

French courts seem impotent when measured by American standards, because the French have been reluctant to establish a strong judicial hierarchy. In this context, the term "judicial hierarchy" includes three concepts: a bureaucratic hierarchy, being a pyramidal structure within which inferior courts follow the direction of superior jurisdictions; a chronological hierarchy, establishing precedents to which later cases must conform; and a jurisprudential hierarchy, of a supra-legislative constitutional norm with which legislative action must comply. Because of the French antipathy to judicial hierarchies, certain American legal doctrines seem incompatible with the French legal system.

For instance, the scope of precedent is highly attenuated. Judicial decisions are not to apply to later disputes. Furthermore, a case may be appealed and reversed, and yet the subsequent trial court may ignore the decision of the appellate court. 6 Thus, not only is the precedential value of earlier decisions de-emphasized but there is no certain "law of the case".

Also, at least until very recently, virtually no judicial review, constitutional or otherwise, of legislation could exist in French jurisprudence. What French control of constitutionality there has been has not been judicial. This does not mean that the French deny the importance of constitutional values. They have rather denied that the constitution gives courts a legal basis for overruling legitimately promulgated legislation. To an American, the notion that the organs of government would, by themselves, respect constitutional rules may seem naive.

The French antipathy to judicial hierarchy is obviously, if crudely, traceable to the French Revolution as a reaction against egregious tyranny under the earlier monarchy and its associated (literal) courts, or Parlements. To combat judicial hierarchy, the

6. See text, infra at $50-51$. 
French have periodically resorted to different arrangements aimed at subordinating their courts to the legislature. And because of this tradition, attempts to create a Supreme Court-either in the sense of imposing bureaucratic hierarchy through final court of review, chronological hierarchy through stare decisis, or jurisprudential hierarchy through a constitutional court designed to impose constitutional values-have been half-hearted. Even the present state of the French judiciary reveals an ambiguity. Whereas most French scholars still recognize both a legislative "power" and an executive "power", 7 the Constitution of 1958 mentions only a judicial "authority"-in contrast to the Constitution of 1946 which, following a constitutional tradition since the Constitution of 1791 , referred to a judicial "power".8 The President is, paternally, the "guarantor of the independence" of the judiciary. ${ }^{9}$

The French rejection of judicial review and binding precedent is unassailable if one starts, as the French have since 1789, with a boundless devotion to pure democracy. Since the Revolution, the development of a special view of democracy ${ }^{10}$ has propelled French politics, particularly as defined in opposition to the Ancien Regime's tyranny. This view of democracy finds its inspiration in the notion of a constituent population from which all legitimate authority comes. Since the source of political legitimacy in French law is located directly in the people and, thus, the legislature, any attempt to defeat that smacks not only of tyranny but also of unconstitutionality. A constitution founded upon popular supremacy tends therefore to define judicial review, which opposes the popular will, as itself illegitimate and unconstitutional.

Not only does the French experience tend to equate judicial review or even a strong judiciary with antimajoritarianism and ultimately with antidemocratic principles, it also raises questions about

7. But see Hauriou \& Gicquel, Droit Constitutionnel et Institutions Politiques 1031 (1981): "Within the context of the institutions established in 1958 it is preferable, it seems, to drop the term legislative power. . . ."

8. Title VII, Const. of 1958; see Perrot, Institutions Judiciaires 48-49 (1983).

9. These words are not a matter of chance: they derive from the notion that the judicial function is a product of the indivisible power of the State for which the President of the Republic has responsibility. They are the negation of the principle that would tend to consider the judiciary as a third power. ...

Perrot, id. at $48-49$.

10. There are several possible definitions of democracy; in fact, perhaps the predominant concern of American jurisprudes today is to define democracy such that it includes anti-majoritarian elements, especially judicial review. The different definitions are suggested by Choper, Judicial Review and the National Political Process (1980); Ely, Democracy and Distrust (1980); Perry, The Constitution, The Courts, and Human Rights (1983); Symposium, "Judicial Review and the Constitution-The Text and Beyond," 8 U. Dayton L. Rev. 443 (1983); and, of course, Hamilton, Jefferson, \& Jay, The Federalist Papers. 
liberalism and its intellectual lackey, the separation of powers doctrine. The French conception of separation of powers differs radically from the American.11 It is functional and essentialistic, claiming that each of the three branches of government has a clear and separately definable domain of conduct into which the other two branches should not enter. Perhaps the most concise description of the "functional" doctrine is that of a "mutual independence of the principal organs",12 as opposed to the American system of checks and balances. This doctrine is far more "rigid", (rigide) perhaps absolutely so, than its more "flexible" (souple) American counterpart. ${ }^{13}$

The conflict between liberalism and pure democracy is highlighted by the French experience. Judicial review is a feature of liberalism but not necessarily of democracy. Liberalism which posits conflict between individuals and groups demands an impartial arbiter of disputes. It requires a legal system which can resolve conflicts and an autonomous body of law to which judges can impersonally refer. This characterization of the judiciary allows liberalism to deny its antidemocratic bias by suggesting that judicial review's restraint on the majority derives not from the minority's desires but from an immanent body of legal principles which dictate the results and which thereby protects majority as well as minority.

The apparent impotence of the French judiciary, by its rejection of both precedent and judicial review, is deceptive if seen as an impotence of law itself. It is simply an attempt to limit, but not destroy, the scope of the legal system, to prevent its intrusion into what the French, at least, see as non-legal, political domains. While this may seem absurd to the American legal scholar, it makes sense in a system which fears a threat of legal dictatorship, a "Government by Judges". ${ }^{14}$

Two examples, one an abortive attempt to impose a hierarchy upon the ordinary courts, the other an almost stillborn attempt to create a constitutional court, illustrate the antipathy to judicial hierarchy and the current controversy over the Conseil constitutionnel. Both attempts vividly demonstrate the French ambiguity over a strong judiciary.

11. See text, infra at 89-91.

12. Troper, preface to Moulin, Le Presidentialisme et la classification des regimes politiques x (L.G.D.J. 1978) (emphasis supplied).

13. Rouban, "L'Inconstitutionnalite du Veto Legislative aux Etats-Unis," 1984 R.D.P. 956-67; see also Troper, infra n. 17.

14. Lambert, Le Gouvernement des Judge et La Lutte Contre La Legislation Sociale Aux Etats-Unis (1921). Typically, the phrase continues to be used as a mildly negative characterization of the real or potential role of the U.S. Supreme Court. Rouban, id. at 949, 968. Vincent, Conseil d'Etat, 22 March, 1945, S. 1945 Part III, 53, 53-54 (note Charlier). 


\section{Attempts at Bureaucratic and Chronological Hierarchy}

Preferring a judicial system which would not make law, but only apply it, one in which a court's interpretation would not bind all later cases, the French Revolutionary Assemblies designed a number of unusual solutions. Already recognized in France was a "right" to a second trial, the "double degré de jurisdiction". The threat of bureaucratic hierarchy posed by the existence of a second, potentially "reviewing", court was at first avoided through the mechanism of the circular appeal (appel circulaire) in which courts of equal status, but different venue, would review each other's decisions.

But this raised other obvious problems ${ }^{15}$ and so, after a few short years, another level, the tribunaux d'appel were created to receive appeals from the trial courts of first instance. Atop this structure sat the Tribunal de Cassation. The potential hierarchy posed by this situation, however, was neutralized by two pre-existing legislative provisions.

The first solution was an "optional legislative reference" which, by requiring that in novel cases the court seek a legislative interpretation, assured that tribunals would not "make law".16 This "optional" legislative reference has not survived, ${ }^{17}$ but the prohibition against regulations or, "arrets de reglements", abusive legislation through quasi-judicial proceedings, was soon codified ${ }^{18}$ in 1804 and persists to this day as Article 5 of the Civil Code. ${ }^{19}$

The second solution was a mandatory legislative reference imposed upon the Tribunal de cassation. The new Tribunal de cassation was prohibited from ordering a particular result in a case or even ordering a particular legal interpretation and could only remand to a different intermediate court for a new trial. After two remands, the Tribunal was required to refer the matter to the legislature, for a binding legal interpretation. ${ }^{20}$ That solved the question of uniformity and finality but merely heightened the constitutional confusion, leaving the French legal system substantially in the position in which it started. To bind a judicial organ through a legislative reference left the nature of the resulting process in grave doubt. Although it avoided the forbidden arrêt de reglement,

15. See Hilaire, Histoire du Droit et des Institutions 323-324 (1975).

16. "They shall not make regulations, but they shall go to the legislative body each time they believe it necessary, whether to interpret a law or to make a new one." Art. 12, Law of 16 and 24 August 1790.

17. See Troper, La separation des pouvoirs et lhistoire constitutionelle française 62 (1980). See also Hilaire, supra n. 15 at 304, 323-324.

18. Hilaire, id. at 315 .

19. "Judges are prohibited from deciding by way of general dispositions and regulations in the cases submitted to them." Art. 5, Civil Code.

20. Art. 21, ch. 5, title III of the Constitution of 1791. 
it seemed to deprive parties of a judicial forum by carrying the Montesquieu formula of separation of powers to its illogical extreme. ${ }^{21}$

In fact, the procedure injected the legislature into judicial matters; to remove all possibility of doubt, the Constitution expressly stated that the Tribunal was "established alongside the legislature".22 This arrangement was criticized and altered through at least half a dozen legislative and constitutional changes, following almost as many changes of government, but the legitimacy of the basic procedure was not formally questioned until 1823, in a decision by the Council of State. ${ }^{23}$ Ultimately in 1837 legislative reference was abolished in favor of a final judicial decision, to be rendered en banc by the Cour de cassation, the successor to the Tribunal.24

The antipathy towards hierarchy left the judiciary in a rather ambiguous state which remains today. The Cour de cassation still cannot directly order a lower court to comply with its wishes. When sitting in full session (Assemblée plenière), it can demand compliance only after two renvois and even then only with respect to the exact question already twice decided. The lower court of renvoi can still base its decision on a different point of law or set of facts. ${ }^{25} \mathrm{~A}$ 1967 amendment allowed the Cour effectively to issue its own decision in those circumstances. But for the first ten years of its existence the provision went unused. A recent more general form of that provision was enacted in $\mathbf{1 9 7 9}^{26}$ but it appears that it has hardly, if ever, been used. ${ }^{27}$

Thus a direct effect of revolutionary passions and desires, the

21. See Geny, Methode d'Interpretation et Sources en Droit Privé Positif 327, 446 (2d ed., trans. La. State Law Inst. 1954). See also text, supra at 47-48. On the other hand, our American system of judicial review, according to one influential French commentator, has "carried the constitutional dogma of Montesquieu to its ultimate logical consequence." Lambert, supra n. 14 at 15.

22. Constitution of 3 September 1791, Title III, ch. V, art. 19. This was not a merely fortuitous choice of words. It formalizes the decision of the framers of the 1791 Constitution to establish a body which would "sit close by the legislature," and thereby achieve uniformity of judicial action without doing violence to legislative intent and supremacy. Lesage, Les interventions du Legislateur dans le Fonctionnement de la Justice 184 (1960), cited in von Mehren \& Gordley, supra n. 4 at 220.

23. Opinion of 17-26 December 1823, Conseil d'Etat, Assemblee generale, 17-26 December 1823, 24 Duvergier, Collection complete des Lois, Decrete, Ordonnances, Reglements, et Avis du Conseil d'Etat 390 (1828). For a helpful English translation, see von Mehren \& Gordley, supra n. 4 at 226.

24. Law of 1 April 1837. The French, however, were still troubled that this finality would interfere with the principle of legislative sovereignty. Geny, in his defense of increased judicial powers, responded in a way curiously anticipatory of the present controversy over the Conseil's nature; Geny, supra n. 21 at 328.

25. An illustration of the potential independence of intermediate courts is "l'affaire Franck". Cass. ch. reun. 2 dec. 1941, D.C. 1942.25, note G. Ripert, S. 1941.1.217, note $H$. Mazeaud.

26. C.o.j.: L.131-5 al. 2, Law of 3 January 1979.

27. Roland \& Boyer, Les Institutions Judiciaires 225 (2d ed. 1983). 
antipathy towards both bureaucratic and chronological hierarchy persists even today in modern France. Contemporary texts insist that French judges simply decide disputes and that their decisions can have no precedential effect. ${ }^{28}$ It is not so simple in practice. Though Article V of the Civil Code forbids courts from issuing such arrêts, it has been observed that the Cour de cassation, simply through its bureaucratic influence, has successfully voided that prohibition. ${ }^{29}$

\section{A Failed Attempt at Jurisprudential Hierarchy}

This same ambiguous development is illustrated in the Comite constitutionnel, the immediate predecessor to the Conseil. The end of World War II also brought an end to the Third Republic and the questionable constitutionality of the government of its immediate successor or final leader, Marshal Pétain. The contradictions of the Pétain government, and the frightening abuses of law, both constitutional and otherwise, of the Nazi era in Germany lent urgency to those who supported greater control of constitutionality or meaningful restraint on potential abuses, in France.

While the Petain government offended the moral sensibilities of many, its legal sin, at least to the legal technician, was its abuse of delegated powers.30 Accordingly, the Comité was only empowered to decide whether legislation entailed amendment of the constitution. Excluded from the grounds for such a decision was that part of the Constitution, the Preamble, which addressed substantive individual rights; left were only those provisions establishing the structure of the three governmental branches.

The Comité could only review a law before its promulgation, could only be seized by a joint request of the President of the Republic and the President of the Council of the Republic, and only upon an absolute majority vote of the Council. The sole legal issue the Comité was to decide was whether a proposed law "implies a revision of the Constitution".31 A finding of unconstitutionality only resulted in submitting the Constitution to an essentially legislative amendment process. ${ }^{32}$ Finally, and perhaps most importantly, the Comite's primary duty, before deciding the legal issue, was to recon-

28. See Hilaire, supra n. 15 at 315.

29. Lambert, supra n. 15 at 2, n. 1 (1921).

30. For a concise, more or less legal, history of the Petain regime, or at least the French view of it, see Guchet, Elements de Droit Constitutionnel 116-117, 231-236 (1981); Hauriou \& Gicquel, supra n. 7 at 841-844.

31. Constitution of 27 October 1946, Art. 91, para. 3; Art. 93 para. 1, Gaz Pal, 1946 L. 406. 406.

32. Constitution of 27 October 1946, Art. 93, para. 2; Art. 90, Gaz Pal, 1946 L. 
cile the two legislative chambers, "to strive to bring about agreement" between the chambers. ${ }^{33}$ Thus, there is some reason to view the Comite as merely a quasi-legislative feature of the new Regime d'Assemblée introduced by the Fourth Republic, rather than as a Supreme Court in any primitive sense. ${ }^{34}$ One might say that it "sat by the legislature". 35

\section{THE CONSEIL CONSTITUTIONNEL}

\section{Substance}

The Conseil Constitutionnel, heir to the traditional French distrust of the judiciary, exhibits its pedigree in two ways. First, its dual function of review and advice shows a mixed lineage of legislative and judicial forebears. Second, its powers of review are constrained within limits reflecting a narrow vision of legitimate judicial activity. Its membership is claimed to be excessively political. It cannot review actual cases nor can any but a very few official bodies seek its review. Its power to declare legislative materials flatly unconstitutional can be exercised only before laws are fully enacted. Its review of already existing legislation is limited to stating whether Parliament has intruded upon the executive domain. It is an exaggeration to call the resulting decision a mere request or suggestion, as with the Comité, but it certainly has an advisory, almost legislative, flavor.

The Constitution addresses the Conseil under a section ${ }^{36}$ separate from the section in which it purports to address exclusively the judiciary. ${ }^{37}$ This is an important point because it textually supports the argument that the Conseil was not meant to have any control over the judicial hierarchy, despite the language of Article 62 which seems to give its decisions finality. In fact, there are two other jurisdictions, each one of which might be considered to be a part of a different juridical order and none having final authority over the other two. The regular courts, under the Cour de cassation, regularly recognize they have no powers to invalidate legislation. ${ }^{38}$ Similarly, while the Council of State controls constitutionality of administrative action, it expressly disclaims any power to invalidate legislation,

33. Constitution of 27 October 1946, Art. 92, para. 2, Gaz Pal, 1946 L. 406.

34. Guchet, supra n. 30 at 117.

35. See supra n. 22; Sueur, Le Regime d'Assemblée et l'elaboration de la constitution de la IVe Republique RPD 1209.

36. Const. of 1958, Tit. VII, Arts. 56-63.

37. Const. of 1958, Tit. VIII, Arts. 64-66.

38. Schiavon v. Ministere public, Cour de Cassation, Ch. crim., 26 February 1974, D. \& S. 1974. J. 273. For a helpful English translation, see von Mehren \& Gordley, supra $n$. 4 at 323,450 . 
in other words, traditional judicial review. ${ }^{39}$ The possibility of conflict between these organs has occasionally become the reality ${ }^{40}$

There are nine members of the Conseil, three appointed by the President of the Republic, three by the President of the Senate, and three by the National Assembly. Their terms are nonrenewable. The President of the Republic may name one of the members of the Conseil President who can then break a tie vote. ${ }^{41}$ In addition to the nominated members, all former Presidents of the Republic have a seat as of right.

Members of the Conseil cannot also be members of Parliament, of the Government, or of the Economic and Social Council.42 During his term, a member can neither be named to public employment nor, if already a civil servant, receive a merit promotion (promotion au choix). ${ }^{43}$

To guarantee the "independence and dignity" of the Conseil, certain obligations are imposed upon the membership. Members are forbidden from taking "any public positions" respecting "questions which are or which might become the object of decisions by the Conseil."44 But there are no prerequisites, such as legal training, for membership. Thus, although a bare handful of jurists have occasionally been named to the Conseil, historically its membership has been composed primarily of political figures. ${ }^{45}$

The Conseil has other duties of advice, administration, and ex-

39. Arrighi, Council of State, 6 November 1936, D. 1938. III. 1, S. 1937. III. 33; for a helpful though partial English translation, see von Mehren \& Gordley, id. at 256. Syndicat general des fabricants de semoules de France, Council of State, 1 March 1968, 1968 A.J.D.A. 235.

40. The Conseil has split with the Council of State on at least three and perhaps four occasions. The most notorious of these concerned the power of the Executive to regulate and punish minor violations with terms of imprisonment. Another was decision 69-55 L. Rec. 27, 26 June 1969, in which the Conseil held that, as a general principle of law, administrative silence constitutes rejection; the Council of State, however, has not accepted this principle. Cne. de Bozas, C.E. ass. 27 February 1970, A.J. 1970.232. In a third situation, the Conseil has held that laws in derogation of valid international treaties, whether enacted before or after such treaties, should be treated by other jurisdictions as invalid. Decision 74-54 DC (Rec. 19), 15 January 1975. The Council of State has consistently rejected that. Rekhou, 29 May 1981; UDT, 22 October 1979; Croissant, d.E., Ass., 7 July 1978. The Cour de cassation, however, has followed the Conseil's lead. Societe Jacques Vabre, ch. mixte, 24 May 1975. Finally, in a fourth situation, the Conseil has held that the principle of "participation" is part of the positive law. Decisions of 5 July 1977, 20 July 1977, 18 January 1978. The Council of State seems to have rejected this. 15 December 1978, D. 1979.327.

41. Const. of 1958, Art. 56.

42. Const. of 1958, Art. 57; Ordinance No. 58-1067 of 7 November 1958, Art. 4.

43. Ordinance No. 58-1067 of 7 November 1958, Art. 5.

44. Ordinance No. 58-1067 of 7 November 1958, Art. 7.

45. Hauriou \& Gicquel, supra n. 7 at 1131 n. 5 (1981); id., Addendum au 30 juillet 1982 , at 64 (1982 supp.). 
amination, such as supervision of elections and referenda, ${ }^{46}$ review of parliamentary procedures, ${ }^{47}$ supervision of impeachment proceedings, ${ }^{48}$ and advice upon declarations of national emergency. ${ }^{49}$ Only its powers to examine or review legislation are further considered here.

The Conseil can review two types of legislative materials in two very different modes. It may review proposed legislation for constitutional violations of any kind, although probably not for violations of the separation of powers doctrine; ${ }^{50}$ or, it may review existing legislation but only for a violation of that particular doctrine.51 Its review of proposed legislation is shared with Parliament, although a legislature is not traditionally thought to be, at least by Americans, a body exercising such a control of constitutionality.

This review of proposed legislation has two constitutional sources. First, under Article 41, the President or a parliamentary chamber may request that the Conseil review proposed legislation to ascertain whether it suffers the particular constitutional defect of invading the executive domain. 52 The Conseil must answer within a week. In a manner reminiscent of the Comite constitutionnel, however, the Government and the Parliament are encouraged to work things out, since review before the Conseil is triggered only "upon disagreement between the Government and the President of the interested chamber."53 The more important source is Article 61, which provides that the Conseil may examine proposed laws for any constitutional defect, inquiring into "their conformity with the Constitution," upon request of the President of the Republic, the Prime Minister, the President of either parliamentary chamber, or 60 of their members. ${ }^{54}$

46. Const. of 1958, Arts. 58-60.

47. Const. of 1958, Art. 61, Ordinance No. 58-1067 of 7 November 1958, Art. 17.

48. Ordinance No. 58-1067 of 7 November 1958, Art. 13.

49. Const. of 1958, Art. 16.

50. Decision 82-143 DC du 30 juillet limited Art. 61 review to disputes not involving allegedly improper legislative intrusions into the executive, regulatory, domain.

51. Both French and American scholars sometimes recognize only the first of these modes as judicial review, reserving for the second some other, more eclectic, term. For instance, French students are taught, in at least one text, that the first process is "Control of conformity of certain acts with the Constitution," while the second is merely "Miscellaneous Duties". Auby \& Ducos-Ader, Droit Public 120-121 (6th ed. 1976). See von Mehren \& Gordley, supra n. 4 at 97. I include them both under review of legislative materials because, as will become clearer, functionally these processes do not radically differ from each other and comparatively the second is not dissimilar from Supreme Court practices which even the French recognize as constitutional control.

52. Art. 41 also provides for review of proposed legislation which arguably conflicts with powers previously delegated to the executive. That procedure, however, does not directly address nor affect the substance of this article.

53. Const. of 1958, Art. 41.

54. Const. of 1958, Art. 61; as revised by Constitutional Law No. 74-904 of 29 Oc- 
The Conseil's review of existing legislation is governed by the second paragraph of Article 37. The Prime Minister is authorized to initiate a proceeding, called "delegalization", to determine whether an existing law impermissibly regulates an area which the Constitution has exclusively assigned to the executive branch. ${ }^{55}$ This review is especially important because of the structure of the present French government under the 1958 Constitution. Under Article 34, Parliament has only specifically enumerated and limited powers, with all non-enumerated powers going to the executive under the first, substantive, paragraph of Article 37, which declares that all powers not specifically assigned to the legislature ${ }^{56}$ belong to the executive. Thus, "delegalization", a finding that legislation has intruded into the executive domain, is similar, though perhaps of a lesser order of magnitude, to a finding of unconstitutionality. ${ }^{57}$

The Constitution purports to grant res judicata effect to decisions of the Conseil.58 The exact meaning of this grant and especially its impact and scope-what constitutes the Conseil's decision and what is surplus-has been debated. It is even more debatable for two major reasons. First, the effect of "delegalization" under Article 37 is not quite the same as a finding of unconstitutionality. A "law" found to enter the executive domain is not thereby nullified. It is simply of "a regulatory character","59 to be altered by executive action. ${ }^{60}$ Until so altered, however, its force as regulation remains. Secondly, two other jurisdictions can interpret, if not review, legislation: the ordinary and administrative courts. Since the Conseil does not "oversee" or review these jurisdictions, it is possible that despite Article 62, differences can occur with no assurance of final resolution. A dubious argument can be made in support of this uncertainty through textual reference to the Constitution. ${ }^{61}$

In none of the above-described instances is the determination of constitutionality related to a case involving litigating parties. In fact, there is no case in the common understanding of the term.

tober 1974. The 1974 revision added the 60 members of Parliament to the other four officials who previously had the sole power to initiate review.

55. Ordinance No. 58-1067 of 7 November 1958, Arts. 24-26.

56. Almost all legislative areas are specifically enumerated, in relative detail, in Art. 34 .

57. See infra n. 247.

58. Const. of 1958, Art. 62 states:

A measure declared unconstitutional can neither be promulgated nor have any effect.

Decisions of the Constitutional Council are not subject to any further review. They are binding upon the public powers and upon all administrative and judicial authorities.

59. Const. of 1958, Art. 37 para. 2.

60. The term "regulatory" is a term of art denoting the executive domain. Its counterpart is "law" which denotes the Parliamentary, legislative, domain.

61. See supra n. 7-9 and accompanying text. 
Moreover, initiation of all the procedures is only available upon petition of a few rigidly defined official bodies or groups, and only prior to the application of a law. Limited constitutional review of existing law-for impermissible legislative intrusion into the executive domain-can be requested only by legislative officials or the government.

\section{Procedure}

Unlike traditional judicial bodies, the Conseil's proceedingsnot just its deliberations-are entirely non-public. No lawyers are present to advocate a particular position; 62 there are no oral presentations. All information presented to the court, what there is of it, is written, and none of that information is necessarily ever disclosed.63

Typically, a statement of position outlining the petitioner's argument and occasionally limiting the object of the petition is submitted. Early practice was to submit it sometime after the letter of petition, but current practice seems to be to combine the two documents. ${ }^{64}$ There have been occasional attempts to submit, with or in addition to the letter of petition, a true brief, or memoire ampliatif, analogous to that submitted in administrative practice. In addition, on at least one occasion, a right to reply was sought but apparently rebuffed. ${ }^{65}$ However, the Conseil itself has the opportunity to gather information, assisted by staff members of the Council of State and Cour des comptes assigned to the Conseil. This includes documents as well as testimony by, or more accurately interviews with, government officials. ${ }^{66}$

A decision is rendered in the typical French single sentence judicial style, the phrase unique. Its format is in the French syllogistic judicial style, with a series of "whereas" phrases leading up to a final "therefore" conclusion. This similarity to normal judicial decisions, and the fact that they are explained (motivée) is partly due to the requirements of an organic law ${ }^{67}$ as well as to more idiosyncratic

62. This, however, is essentially the same procedure as before two other French courts of recognized juridicality, the Tribunal des conflits and the Cour des comptes.

The only time there was an attempt to retain a lawyer, which was made by some legislators contesting a law altering the status of state workers, it was apparently unsuccessful. Lebreton, "Les Particularites de la Jurisdiction Constitutionnelle," 1983 R.D.P. 419, 441. Favoreu \& Philip, Le Conseil Constitutionnel 25, P.U.F., Que SaisJe?, no. 1724 (2d ed. 1980).

63. Favoreu \& Philip, id. at 25-26.

64. Lebreton, supra n. 62 at $419,426$.

65. Id. at 419,441 .

66. Favoreu \& Philip, supra n. 62 at 25-32; see also, Hauriou \& Gicquel, supra n. 7 at 1053.

67. Lebreton, supra n. 62 at $419,428$. 
reasons. ${ }^{68}$

There is no dissent, no mention of which members participated, no vote tally, nor the name of any author. ${ }^{69}$ Some of these details, however, can be gleaned from the popular press, and such reports appear, in fact, to be the accepted-or expected-source for this information. ${ }^{70}$ In the twenty-five years of its existence, the Conseil has developed a rich practice according to which it occasionally refuses to decide all that is apparently before it, equally occasionally seems to decide more than was originally presented, or, alternatively, couches its decisions within certain hypothetical limitations (reserves) which it assumes in its decisions. Often, these limitations are assumptions about the scope of a challenged law, assumptions which, if binding, become restrictive interpretations. ${ }^{71}$

\section{THE Issues}

Is the Conseil a "court"? Two widely-respected French authors seem quite positive:

This issue is hardly anymore even the object of discussion today. It is recognized that the Conseil acts as a judicial body (jurisdiction), not only in electoral matters, but equally in the other cases with the exception of those, very rare, where it is must issue an advisory opinion. ${ }^{72}$

But two American scholars question the Conseil's nature; von Mehren and Gordley claim that, " [s]tanding apart both institutionally and functionally from the regular- and administrative-court hierarchies is the Conseil Constitutionnel."73 Despite the fact that the Conseil Constitutionnel sometimes declares proposed statutes unconstitutional and has "delegalized" numerous laws for having overstepped constitutional bounds, French scholar Denis Tallon seems to agree that the Conseil is not a court, stating, "in France, there is no control of the constitutionality of legislation by the courts."74 Similarly, Cappelletti and Cohen declare: "The Conseil Constitutionnel

68. Ordinance No. 58-1067 of 7 November 1958, Arts. 20, 26.

69. However, recently, and for the first time, in connection with the decision of 16 January 1982 relative to the nationalization laws, the reporter's identity became known, when a supplementary statement of position attached to the letter of petition was addressed personally to him. Hauriou \& Gicquel, supra n. 7 at Addendum au 30 juillet 1982, 63 (1982 supp.).

70. See Favoreu \& Philip, supra n. 62 at 25; see also, Balat, La Nature Juridique du Controle de Constitutionnalite des Lois dans Le Cadre de l'Article 61 de La Constitution de 1958, 39 n. 22 (1983), and accompanying text, which takes issue with others who claim that such press reports can actually function, in a jurisprudential fashion, as a substitute for the lack of party litigation before the Conseil.

71. Lebreton, supra n. 62 at $419,472-483$.

72. Favoreu \& Philip, supra n. 62 at 5.

73. Von Mehren \& Gordley, supra n. 4 at 97.

74. Tallon, supra n. 3 at 567. 
is not a judicial body. It is a political institution. . . ."75

However, the vitality of the issue may relate more to political circumstances than to settled jurisprudential ideas. Its resolution may depend upon what the Conseil-as a highly political issue if not a political institution-does. ${ }^{78}$ The recent controversial decision invalidating part of the nationalization laws revitalized the issue, at least temporarily. After that decision, the Socialists coined a new word, normocratie, to describe what they regarded as the Conseil's illegitimate substitution and use of supra-legislative norms for, and in place of, legislative rules: "We represent the people", said Pierre Joxe, leader of the Socialist coalition, "They represent the political majority of an earlier time."77

In the debate over the nature of the Conseil nature, there are two somewhat different strands in the thread of the argument. One seems to discuss the Conseil solely in the restrictive light of French tradition. The other approaches the subject from a broad jurisprudential perspective including the expansive American tradition and, within it, the U.S. Supreme Court as one example of a juridical body. Since the Conseil obviously determines the constitutionality of legislation, the first strand can easily reach a pat conclusion of non-juridicality on the grounds that French courts simply do not do that.

Whatever motivates the dispute, it seems to resolve into the six categories previously mentioned ${ }^{78}$ : membership, subject-matter, non-contradictiousness, procedure, jurisdiction, and institutional design. ${ }^{79}$ Tallon's position is representative, addressing all six issues:

The Conseil constitutionnel is an innovation. ... Its main function is to supervise the conformity of acts of Parliament, as to their constitutionality. But it does not perform this function as a judicial body. ... In the Constitution, it is described in a separate title . . . not under the heading of the judiciary. ... Its nine members do not have the status of judges. They are nominated in equal numbers by the President of the Republic and the Presidents of the two Houses. Moreover, ex-Presidents of the Republic are ex-officio members. ... [A]n action may be brought only by a limited number of persons. ... [N]o one else, and no indi-

75. Cappelletti \& Cohen, Comparative Constitutional Law 29 (1979).

76. Favoreu, "Le Consell Constitutionnel et l'Alternance," Rev. Française Science Pol. 102-128 (aout-octobre 1984).

77. Hauriou \& Gicquel, supra n. 7 at Addendum au 30 juillet 1982, 63 (1982 supp.).

78. See supra n. 5 and accompanying text.

79. A fairly comprehensive discussion is contained in Luchaire, "Le Conseil Constitutionnel Est-Il Une Jurisdiction?," 1979 Rev. Dr. Pub. 27. 
vidual, has access. . . . Those who have must act immediately . . . before promulgation. . . . Finally, this control is reserved to acts of Parliament. Executive and administrative regulations are outside ... the Conseil's control. ${ }^{80}$

Similarly, Brown states, with respect to membership, subject-matter, and non-contradictiousness:

Certainly, the Council's functioning is far removed from American notions of judicial review. It does not have the guarantees of impartiality and independence associated with a true court. It acts only before a law has gone into effect, and is in no way open to the individual citizen who may be harmed by the law. ${ }^{81}$

He concludes, unsurprisingly, "The Council is not really a constitutional court at all."82 Addressing only membership and institutional design, von Mehren and Gordley state:

... the Council is not considered to be a court in the full sense of that term. This view is based in part on the Council's composition-one-third of its nine members are appointed every three years for nine-year terms by the President of the Republic, the President of the National Assembly, and the President of the Senate-and in part on the conception that the drafters of the Constitution had of the Council. The question remains whether the Council may, in time, evolve into a true court, exercising judicial review over legislation. By 1976, certain events suggest that such an evolution may be under way. However, development in this direction faces great institutional and political obstacles. ${ }^{83}$

The definition of a "true court" is the heart of the dispute. It raises the more fundamental definition of law and its autonomy from politics. Implicit in all the arguments raised against the Conseil's judicial nature is that there exists a radical dichotomy between law and politics and between "true" courts and political bodies. It seems significant, therefore, that Cappelletti and Cohen deny the judicial nature of the Conseil but fail to define a court, instead simply asking, "What are the characteristics of a 'judicial' rather than 'political', organ of government"? ${ }^{84}$ To be fair, the authors add that "since 1971, the Council has begun to develop into an effective, in-

80. Tallon, supra n. 3 at 567,569 (1979).

81. Brown, "DeGaulle's Republic and the Rule of Law: Judicial Review and the Conseil d'Etat," 1966 Boston U.L. Rev. 462, 469 (emphasis supplied).

82. Brown, id. at $462,469$.

83. Von Mehren \& Gordley, supra n. 4 at 121.

84. Cappelletti \& Cohen, supra n. 75 at 72. 
dependent organ"85 (although still not ascribing to it a judicial nature), and hedge their bets by adding, "it was not originally intended to be a judicial organ of review."

The critics can be confident that their views were shared as well by the drafters of the 1958 French Constitution. Right or wrong in their views about the nature of law and courts, the drafters intended, as Barry Nicholas says, to create a body with limited powers of legislative review, "conceding to the Conseil as few judicial characteristics as possible." 87

For the French, the problem is more than just historical, and not merely theoretical, because it raises real and practical concerns. At stake are the goals of conflicting political agendas. To examine the French system, and to recognize what the Conseil does, involves a redefined notion of law in relation to politics. But it is naive to believe, as one former member of the Conseil claims, that it is only an "academic" question.88 It is, as Luchaire intimates, a political act. ${ }^{89}$ Its resolution has profound consequences in two domains, the political and the legal.

Politically, public criticism of the court and frank discussion of its composition is more acceptable if the Conseil is considered a political body.90 Perhaps because of the unresolved question over the Conseil's nature, such criticism has itself provoked serious political controversy in the past few years.

Legally, certain consequences, many of them statutory, follow from a juridical characterization of the Conseil. The attachment of res judicata to its decisions, the requirement that a court consider all questions raised, the limited right of judges to certain redress or remedies against those who act contemptuously of or try to influence the court, the limited right of others to sue for defamation for statements made to a court, and the immunity of the state and of judges for judicial acts, follow from a juridical characterization. Finally, judicial procedures which insure fairness to all those involved-and which serve as the justification for the immunity of judges and the state-would apply to a juridical body. ${ }^{91}$

\section{Membership}

While there are numerous issues which divide opinion upon

85. Id. at 29.

86. Id. at 47.

87. Nicholas, "Fundamental Rights and Judicial Review in France," 1978 Pub. $L$. 82, 84 (1978).

88. See infra n. 176 and accompanying text.

89. See Luchaire, Le Conseil Constitutionnel (1980).

90. Id. at 33.

91. Id. at 33-35 (1980). 
whether the Conseil is a court-and, by implication, on whether law can be characterized in one way or another-none has been so divisive for the French-surprisingly so to an American-as its "original sin",92: the selection of its members. It has been called the "essence" of the dispute. ${ }^{93}$ Cappelletti and Cohen include the composition problem among their list of the Conseil's "congenital defects".94 Upon the 1974 revisions to the 1958 Constitution, Patrick Juillard noted that the revisions failed to produce the true Supreme Court composed of independent members that its sponsors, critics of the original 1958 arrangements, had desired. ${ }^{95}$ Brown has also observed this "lack of independence". ${ }^{96}$ Others have bemoaned the quality of the Conseil's members, observing that "[v]ery few have distinguished themselves as legal scholars." 97 Juillard contrasted this failure with the striking success of the U.S. Supreme Court to assert its independence in Marbury $v$. Madison, and attributed the differences to the selection of its members. ${ }^{98}$

Similarly, Hauriou recognizes the selection process as a serious problem. First, he tends to dismiss its relative significance in the larger scheme of things, intimating that the Conseil has "essentially a judicial nature".99 But then, in a rather typically French manner, he finesses the problem by inventing a new category, the "parajudicial" into which he claims the Conseil appropriately fits.100 Duverger does essentially the same when, recognizing the importance of the selection process, he characterizes the Conseil as "a kind of a supreme political court". ${ }^{101}$

\section{Subject Matter}

Tallon says-not quite mournfully-that the bar against review of post-promulgation legislation creates an insuperable barrier between the Conseil and true judicial review along American lines. This objection is raised by numerous critics, and Tallon's position is

92. Juillard, "L'Amenagement de l'Article 61 de la Constitution," 1974 Rev. Dr. Pub. 1703, 1767.

93. Franck, Les Fonctions Juridictionelles du Conseil Constitutionnel et du Conseil d'Etat dans l'Ordre Constitutionnel 14 n. 6 (1974).

94. Cappelletti \& Cohen, supra n. 75 at 47.

95. Juillard, supra n. 92 at $1703,1723$.

96. Supra n. 81.

97. Cappelletti \& Cohen, supra n. 75 at 47 . The effect on judicial independence of such imponderables as status or even of such measurables as salary is, of course, speculative. Waline notes that though the members of the Conseil are not formally judges, they enjoy a " "comfortable' but not scandalously high," salary. Waline, "The Constitutional Council of the French Republic," 12 Am. J. Comp. L. 483-493 (1963).

98. Juillard, supra n. 92 at $1703,1767$.

99. Hauriou, supra n. 7 at 1093.

100. Id. at 1097.

101. Duverger, Droit constitutionnel et Institutions politiques 638 (4th ed. 1955) (emphasis added). 
representative of its central point. The bar against such unlimited review creates "[t]he main difference" between the French and American systems, since it prevents the Conseil from recognizing, and adapting constitutional law to "changing notions of constitutional rights." Therefore, he says, the Conseil can not be the "keeper of the nation's conscience" like the U.S. Supreme Court.102

Others raise the same point more obliquely or theoretically. Thus, Juillard, whose theory Luchaire characterizes as the most "compelling" (seduisante), ${ }^{103}$ insists that the Conseil is "institutional" rather than judicial. He elaborates a theory of constitutional control characterized by two modalities of action with the judicial at one pole and the institutional at the other. Our Supreme Court is, to Juillard, the paradigm of an organ occupying the judicial modality. ${ }^{104}$

These two modalities share only one thing in common: "to assure the supremacy of the Constitution over Law". ${ }^{105}$ Otherwise, there is a profound difference between the two: whereas judicial bodies operate to destroy law, institutional bodies operate in order to create law. This distinction between bodies which "make" law and those which "take" law has led one French scholar to conclude that the Conseil is actually a legislative organ. ${ }^{106}$

Three fundamental differences reflect this profound distinction, according to Juillard: the Conseil performs its work before the creation of legislation, it is exclusively dissociated from the application of legislation to actual cases, and its control is exhaustive rather than limited. Only the first is relevant here as a subject matter issue. It relates to the fact that Article 61 requires that the Conseil act only prior to the promulgation of legislation. The second and third are essentially due to the fact that there is no contradictiousness. ${ }^{107}$

\section{Non-contradictiousness}

The two elements of Juillard's theory ${ }^{108}$ which address non-contradictiousness are the dissociation of proceedings from the application of legislation to actual cases and the fact of exhaustive rather than limited control (that is, that a finding of unconstitutionality is not limited to a particular case and particular litigants but exhaustively invalidates the law).

102. Tallon, supra n. 3 at 567,575 (1979).

103. Luchaire, supra n. 9 at 17,33 (1979).

104. Juillard, supra n. 92 at 1703,1706 n. 4,1707 , and 1707 n. 8.

105. Id. at $1703,1706$.

106. Balat, supra n. 70.

107. See infra, text accompanying n. 108.

108. See supra, text accompanying $n .104$. 
Dissociation of the proceedings from litigation is a matter of non-contradictiousness, relating to the absence of any "case or controversy" requirement. According to strict, traditional French legal theory,

A judicial body is one whose function is to apply the rule of law to disputes brought before it by individuals asserting in good faith contradictory arguments. ${ }^{109}$

The notion of exhaustive rather than limited control is, also, a feature of non-contradictiousness. It, too, is essentially a case or controversy issue, arising out of the absence of any adversary procedure (controle au contentieux) and is due to a different type of constitutional norm, says Juillard, which the Conseil applies. Because the norm applied by the Conseil controls the entire panoply of intra-governmental relationships (l'organisation et . . functionnement des pouvoirs publics) under separation of powers doctrine, rather than provisions solely implicating individual rights, there is no requirement that a party show injury (there is, of course, no "party" in the American sense at all). In discussing this issue, Juillard only uses the English phrase, "standing to sue", because, he says, it is "untranslateable". 110

\section{Procedure}

Hamon emphasizes the lack of "the structured contribution of interested parties to inform the court". ${ }^{111}$ Chenot, a former member of the Conseil, says:

I never thought for a moment that the Constitutional Council was a judicial organ; it is a political body by its membership and by the functions it performs.

[T] here is no hearing before the Constitutional Council; there is no hearing, there are no parties; there are no arguments and still less publicity of arguments. ${ }^{112}$

Similarly, Waline emphasizes the entirely written nature of the procedures before the Conseil and the secrecy of deliberations. ${ }^{113}$ Philip and Favoreu also recognize this as a potential criticism, although they minimize its importance. ${ }^{114}$ Nicholas, too, tends to minimize the procedural problem. Although he notes that the short time in which the Conseil must act "may produce ill-considered deci-

109. Juillard, supra n. 92 at 1703,1708 .

110. Id. at 1709.

111. Hamon, Institutions et vie politique, v. II at 262 (1975).

112. Chenot, Le domaine de la loi et des reglements (colloquium at the University of Aix-Marseille) at 134 (1977), cited in Luchaire, supra n. 79 at 27, 31.

113. Waline, supra $n .97$ at $483-493$.

114. Favoreu \& Philip, supra n. 62 at 27. 
sions", ${ }^{115}$ he still considers the Conseil a judicial body, the problem being simply that "[i]ts procedure does not yet accord with its true character."116

\section{Jurisdiction}

Because the Conseil does not exercise exclusive control over constitutionality, there are those who claim that it cannot be a true Supreme Court. The possibility of inconsistent decisions between it and the Council of State as well as the Cour de cassation, raises serious questions. Waline notes that the Conseil's shared power with at least one other jurisdiction, the administrative courts; seriously undercuts the Conseil's position as a "supreme court", because, in contrast to the U.S. Supreme Court, there is always the possibility that a decision will not be universally respected.117 That possibility has become the reality on three or four occasions. ${ }^{118}$

But the jurisdictional problem is the Conseil's most paradoxical. Due to the historical French view of judicial process, a claim that the Conseil is a court can effectively limit, rather than enlarge, its authority.

It is a circular argument, starting from the fact that French courts have limited powers. The scope of a decision, the chose jugée, binds only those involved in the particular dispute. Article 5 of the Civil Code ensures that courts cannot issue arrêts de règlement, extending their powers beyond the case. ${ }^{119}$ On the other hand, a legislative act has almost unlimited scope, actually making the law.

Thus, in an ironic twist, in order to avoid giving legislative scope- "the sovereign authority of the rule of law"-to the Conseil's decisions, the Government has effectively argued that the Conseil is a court, having only "the simple authority of res judicata (chose jugée)". ${ }^{120}$ In other words, it is only if one considers the Conseil to be a court that it cannot exercise judicial review like the Supreme Court! But this is more than mere irony, for the jurisdictional problem, if conceived as a bar to defining the Conseil as a judicial body, is a problem only if it is first accepted as a court in the restrictive French sense. It is therefore more a problem dictated by a political agenda than one dictated by the inherent nature of the Conseil constitutionnel.

115. Nicholas, supra n. 87 at 177 , n. 2.

116. Id. at 177.

117. Waline, supra n. 97 at $483-493$.

118. Supra n. 40.

119. See supra, text accompanying $n .16$ and n. 15-29.

120. Favoreu \& Philip, Les grandes decisions du conseil constitutionnel 282 (2d ed., 1979). 


\section{Institutional Design}

A final criticism has been that the Conseil was intended, in 1958, to answer the institutional demands of a newly expanded executive for strict control over legislative intrusions into the executive's expanded prerogatives. The thrust of this criticism, therefore, is twofold: first, that the original intent of the drafters of the Constitution was not to create, out of the Conseil, a court; and, secondly, that the Conseil was designed to maintain a supposed bias against the legislature in favor of the executive. Michel Debré, a kind of Madison of the 1958 Constitution, more or less admitted this, calling the Conseil a "special institution". ${ }^{121}$

And, it is substantially true that the Conseil was created by deGaulle, or indirectly so through his agents, to be the handmaiden of the executive. Serving solely to constrain the legislature, it can be viewed in this way as merely another political organ. ${ }^{122}$

\section{Summary}

Those who claim the Conseil is non-judicial because of the above features apparently believe these features are non-judicial; that is, that law does not consist of such features and is distinguished from some other domain by their absence. Implicit therefore is the following jurisprudential belief: what courts do and what the executive or legislature does are two different things. Courts are judicial, and function within legal constraints. The constraints upon executive and legislative functions, however, are not legal; they are political. The jurisprudential problems facing both the French and ourselves are similar, perhaps identical: defending the law/politics distinction after the advent, for them, of "free scientific research", 123 for us, of Legal Realism. ${ }^{124}$

\section{ATTEMPTED RESOLUTIONS}

The commentators address the foregoing issues from one of three positions. Underlying each is an implicit view of the law/poli-

121. Debré, Address to the Council of State, 27 August 1958, in Documents d'Etudes, Droit Constitutionnel et Institutions Politiques 21 (1976).

122. Waline, "Foreword" to Favoreu \& Philip, supra n. 120 at xi (1979). See Bermann, "French Treaties and French Courts: Two Problems in Supremacy," 28 Int. \& Comp. L.Q. 458 (1979).

123. Geny, supra n. 21; Ehrlich, Freie Rechtafindung und Freie Rechtswissenschaft (1903); id., Soziologie und Jurisprudenz (1906); Flavius, Der Kampf um die Rechtswissenschaft (1906); see, David, Intnt I. Encycl. of Comp. L., Vol. II, Ch. III, 3269 (1984).

124. Tushnet, "Legal Realism, Structural Review, and Prophecy," 8 U. Dayton L. Rev. 809 (1983). 
tics distinction. The conventional position maintains the distinction; the skeptical position questions it; the avoidance position ignores it.

1. The conventional position uses untested inductive premises, yielding two approaches, the functional and the formal. The functional adopts some jurisprudential definition, applying it to various Conseil attributes. Within this are two progressively more particular variants, the evolutionary and the ironic. The formal approach holds that a juridical nature is determined by an organ's structural status within public institutions or its textual status within the Constitution and laws.

2. The skeptical position regards juridicality as problematical, chimerical and contingent. The dominant approach is realist-skeptical, holding that an organ's juridical nature depends upon sociological factors. A logical extension of that would be critical-skeptical, viewing the issue as problematical because difference between legal and political, between judicial and legislative, is merely one of strategy and agenda and that jurisprudential definitions are a product of political goals.

3. The avoidance position simply finesses the issue.

\section{The Conventional Position}

\section{A. Functional}

Most critics adopt functional arguments, reaching their conclusions, much like the formalist, by analogy to other political or judicial institutions. For instance, Waline argues that the judicial nature of a state organ is determined more by its acts and functions, than by its form or its label. Under his theory, a state organ acts judicially when it fulfills two requirements. The first is formel (in the sense of the formal organization of state organs and their respective powers): the decisions must be binding on other state organs (l'autorite de la chose jugée), not as res judicata estoppel, but as a finality which distinguishes a judicial decision from an advisory opinion. The second is materiel (in the sense of the subject matter of the decisions, not in the sense of a strict procedural-substantive dichotomy): its decisions must be based upon and expressed by reference to positive, State-derived law. ${ }^{125}$ Having posited these two re-

125. Note that this part of Waline's test is more formalistic than functional. Waline, "Foreword" to Favoreu \& Philip, supra n. 120 at vi. Franck conducts a parallel analysis, reaching much the same conclusions. The formel and organique features of a judicial body, according to him, include its organization, membership, independence, and procedures. The materiel features include the resolution of disputes, the use of rules of law, and the goal of maintaining the juridical order. Franck, supra n. 93 at 14-27. The terms are confusing because, deriving from the civil law formal/material method for classifying state organs, they are almost the reverse of English terminology: the formel element is a substantive one relating to the 
quirements, Waline insists that: "A judicial body (jurisdiction) is essentially defined by the two already indicated elements, and by them alone."126 But in the final analysis, Waline's reasons seem more inductive than ineluctably logical and derive whatever persuasive force they have from an intuitive argument based on reference to organs that seem indisputably judicial or, as he says, those which are "unanimously considered to be judicial".127 It is only through such an appeal to intuitive common sense that this part of the argument is justified.

Waline denies that it is inconsistent, or at least nonjudicial, for a state organ to possess some nonjudicial traits. He insists that a state organ can, in effect, have two characters. ${ }^{128}$

Waline also disposes, almost too easily it would seem, of the classical requirement for adversary proceedings, noting bodies which are non-adversary but whose juridicality "no one doubts". ${ }^{129}$ The ultimate recourse to what "no one doubts" is troublesome. The argument is even more vulnerable in light of his claim that state organs can have multiple characters. It is not clear, when he refers for inductive proof to organs that "no one doubts" are judicial, that it is their judicial traits, rather than their non-judicial ones, which support his argument.

In other words, if the Conseil can be judicial at times and nonjudicial at others, it must be equally possible, statutory command aside, for the Cour des comptes to be nonjudicial at times, despite the fact that "no one doubts" it may be judicial at others. Thus, reference to noncontentious Cour proceedings hardly proves, at a jurisprudential level, that the Conseil is a judicial body unless it is first demonstrated that these proceedings constitute the judicial part of the Cour's activity. But that, of course, is the conclusion that Waline is trying to reach and he can hardly use it as his premise.

Waline implies from this (though nowhere explicitly states) a difference between the presence of adverse parties and the presence of competing issues. One need not have adverse parties to have a judicial proceeding, says Waline, and thus even if the Conseil frequently acts without such opposing parties (en presence de deux prétentions opposées), ${ }^{130}$ there are clearly constitutional issues raised and a decision between such competing issues. Because these deci-

actual authority accorded a decision by the other organs of the State; the materiel element is really a formal one, see infra, n. 165-166 and accompanying text, in our terms, because it only addresses such features as the language used by the organ.

126. Waline, "Foreword" to Favoreu \& Philip, supra n. 120 at vi.

127. Id. at $\mathrm{v}$.

128. Id. at vi.

129. Id.

130. Id. at viii. 
sions have binding force and are articulated in terms of positive law, Waline's requirements of juridicality are met.

Taking an equally functional approach, Waline says that the composition of the Conseil must be judged by practical assurances of independence, not by abstract formalistic notions. ${ }^{131} \mathrm{He}$ rejects the notion that the Conseil is biased in favor of the executive but he relies on an assumption incompatible with judicial independence: the Conseil cannot be partial to the executive "if one realizes that two thirds of its members are named by the presidents of the two parliamentary assemblies."132 Moreover, any such argument as Waline's, which relies upon a comparison with the High Court of Justice, rings hollow when one considers that the High Court itself has been described as "basically a court of an exceptional character, concerned with rendering political justice."133

Luchaire advances an equally functional argument, claiming that it is not useful to assign juridicality to an entire state organ but only to its various functions. . $^{134}$

[C]an it be said that that there is never a hearing, nor parties, nor opposing debates before the Constitutional Coun-

cil? Certainly not. . . . 135

He notes that when a law is reviewed under Article 61, all of the major government bodies and officials are notified and each can submit written arguments; the same is essentially true of the real differences of position in an Article 37 proceeding when the Government effectively responds to the implied claims of the Parlement which enacted the questioned laws.

In each of these situations, Luchaire notes the significant presence of dispute (contestation), the resolution of which becomes an important criterion of judicial action. Moreover, even where parties do not raise the issue, such as in the self-assertion of jurisdiction over organic laws (the non-contentious issues of which Waline speaks), it is not how the dispute is raised so much as its existence; it is not the presence or absence of an individual raising the question which determines the judicial nature of the institution but, rather, the function performed. ${ }^{136}$

Luchaire fashions a functional definition, concluding the Conseil is judicial because of his two "criteria of juridicality":

131. Id. at vili.

132. Id. at $x i$.

133. Auby \& Ducos-Ader, Droit Public 121 (6th ed., 1976).

134. See supra, n. $46-49$ and accompanying text. There is no disagreement that, recognizing the widely diverging and various responsibilities of the Conseil, not all, if any, of its functions can be judicial.

135. Luchaire, supra n. 79 at 34.

136. Id. at 35. 
[T] here is a (contentious) judicial decision when there is a resolution by a definitive decision of an adversely disputed matter bearing on a question of law....

[T] here is also a judicial decision when there is a response accorded judicial finality to a question of law, even in

the absence of adversely disputed matters (toute contestation). . . .137

Luchaire explains that his formula is two-fold to include both Waline's argument ${ }^{138}$ and Juillard and Hamon's requirement of contentiousness ${ }^{139}$ and to recognize that it is when finality is unclear that juridicality is most frequently questioned.

Thus, where the Constitution specifically supplies res judicata effect (Article 62) ${ }^{\mathbf{1 4 0}}$ all that is required to conclude an organ is judicial is that it couch its decision in legal terms. On the other hand, where res judicata is not expressly mandated by constitution or statute, a conclusion of juridicality is supplied only by a final resolution of adverse interests. But it is the very finality of the resolution which seems at issue, for only judicial decisions have that character. As Balat notes, ${ }^{141}$ this is circular. Under Luchaire's test, given adverse interests, a conclusion of juridicality is apparently in the hands of the organ itself.

Equally surprisingly, Luchaire concludes that the Conseil's composition is irrelevant to its juridical nature. In an argument bottomed upon the law/politics distinction, he states that a political nature implies political accountability in that, unless a body is accountable and responsible to a political group, it is meaningless to call it political. In this sense, the government is accountable to the Parliament which can dissolve it and the President is accountable to the people who possess the powers of referendum, censure, and reelection; the Conseil, however, is accountable to no one. ${ }^{142}$ Equally important, Luchaire claims that even the membership of the Conseil

137. Id. at 37.

138. See supra, text preceding and accompanying $n$. 125.

139. Hamon, supra n. 111 at v. II; Juillard, supra n. 92 at 1703; see also supra, text accompanying n. 103-107.

140. I use the term res judicata basically because the French refer to it in that way (chose jugée). However, in the context of Conseil proceedings, it is very much the same as the term stare decisis. This is partly due to the fact that, as a student of mine observed, the two terms tend to merge when there are no parties involved. However, it is mostly due to the fact that the French simply do not freely acknowledge the concept of stare decisis with all its threat of chronological hierarchy. Instead, they seek a more modest form of finality in res judicata. To the extent that Lambert is right, see supra n. 29 and accompanying text, French res judicata leads to stare decisis anyway.

141. Balat, supra n. 70 at 16-17.

142. Luchaire, supra n. 79 at 33. 
cannot affect its juridical nature, as long as it operates as a judicial body, because, separating recruitment from function, juridicality depends upon what is done, not upon who does it. ${ }^{143}$

More than most other functional arguments, Luchaire's seems premised upon a jurisprudential definition rather than an ad hoc one. He strongly implies that the formal argument has things backwards; he demonstrates that the political composition of the Conseil does not determine its juridical nature; its composition is a matter or prudence, not principle. It is only after he concludes that the Conseil is judicial that he then asks the question: "Does its composition assure the guarantees of independence of impartiality and of competence that everyone expects of a court?"144 He thus relegates the membership problem to a secondary, non-definitive, position. Implicitly recognizing that there may be "courts" which do not meet our expectations of independence, he insists that their judicial nature nevertheless remains.

Balat starts from a formal position, but quickly demonstrating that formalism leads nowhere, ${ }^{145}$ develops a jurisprudential definition of juridicality which differs little from Luchaire's. Unlike most other functionalists, Balat, in developing an inductive definition of juridicality, relies heavily upon many other foreign jurisdictions in addition to the United States. ${ }^{146}$ His conclusion, however, is highly idiosyncratic: the Conseil, when it determines the constitutionality of laws, is neither political, judicial, nor entirely unique; it is a legislative organ! He suggests that the Conseil abandon its juridical pretensions, and "its editorial style which only specialists can decipher," because "in a democracy, power should not be obscure or secret",147 and finally implores, "If only the Constitutional Council would 'kill the whereases, never would a death have been so just'!"148

In questioning the supposed institutional bias of the Conseil towards the executive, Bermann, too, employs a functional argument. He notes that the one-way nature of the Conseil's procedures is more apparent than real and more textually formal than functional, since Article 34, though only expressly limiting Parlement, can effectively determine the executive's powers also. ${ }^{149}$ Thus, juridicality cannot be determined solely by labels nor even by constitutional

143. Id. at 27.

144. Id. at 27,52 (1979).

145. See Balat, supra n. 70 at 25.

146. Id. at $20-21,51-52,56-57,63-65$.

147. Id. at 79-80.

148. Id. at 80 , quoting Larche, "Le Conseil constitutionnel organe du pouvoir d'Etat," 1972 A.J.D.A. 137 (March 1972).

149. Waline makes a similar observation. Waline, "Foreword" to Favoreu \& Philip, supra n. 120 at xi. 
text but only by the final operational result. ${ }^{150}$

\section{Evolutionary-Functional}

Within the functionalists there are those who believe an organ can develop judicial characteristics through time. There is more than a touch of legal realism to this approach. Rivero's argument emphatically embraces the Conseil as a judicial institution. His analysis, however, emphasizes the development of the Conseil over time, relating it to social and political developments. In his view, the juridical nature of an organ, and in a way one's definition of law, is indeterminate without reference to, and thus contingent upon, the social environment. Rivero is untroubled by the exact textual constitutional source of the Conseil, its method of designating members, and even the limitations on "standing". He notes that the Conseil has adopted procedures and positions which have gained public confidence; and that the Conseil's acts contradicted the pessimistic expectations of some early critics, effectively establishing new constitutional tradition. . $^{151}$ He concludes, "the Conseil's judicial nature, which had been doubted on account of its consultative functions, is no longer denied."152 Clearly, unless one takes Goguel's position that the question is merely "academic", 153 Rivero's position that the judicial nature of the Conseil simply grew, surprising everyone, is curious. The nature of the Conseil, apparently, does not depend upon exclusively "legal" factors, because its nature depends upon people's reactions and the passage of history. ${ }^{154}$ It seems possible under Rivero's view that what could be judicial could also be political, depending upon circumstances. If the French had been more reluctant-or, perhaps, hasty-to use the Conseil or if its members had been less bold-or, perhaps, more cautious-it might have been a purely political organ. ${ }^{155}$

\section{a. Ironic-Evolutionary-Functional}

An even more specific variant of the evolutionary might be called the ironic. It implies that Parliament unwittingly created a Frankenstein's monster, ${ }^{156}$ and that though the original intent was

150. Bermann, supra n. 122 at 484.

151. See Rivero, "The Constitutional Protection of Human Rights in French Law," 12 Irish Jurist 1, 10-11 (1979).

152. Id. at 10.

153. See, infra n. 175 and accompanying text.

154. See Boucher, "Defaites," Le Monde (14 January 1977). (The Conseil is an "adolescent jurisdiction".)

155. See also von Mehren \& Gordley, supra n. 4. ("The question remains whether the Council may, in time, evolve into a true court . . . By 1976, certain events suggest that such an evolution may be under way.")

156. Baudouin, answering the government's claim that the Conseil was not a judi- 
not to create a judicial organ, the framers were mistaken about judicial characteristics and created a court in spite of their intentions. The substance of this variant is that not only can a judicial nature evolve but it can defy a clearly contrary desire.

Those who claim the intent was to create a non-judicial organ are on fairly secure ground, of course. Debré's statement to that effect, ${ }^{157}$ just prior to the Constitution's adoption, is relatively authoritative. ${ }^{158}$ But Waline contrasts that intent with the actual effect of the 1958 Constitution which, he claims, was to create a court. ${ }^{159}$

Bermann also maintains that though the framers of the Constitution did not intend to create a court, they did so nonetheless, and produced an organ which performs what is, in substance, judicial review. This highly functional position reduces the need to examine the exact juridical nature of the limitations on the Conseil by denying the import, if not the reality, of those limitations. Sanguine, for instance, about the jurisdictional problem, he states that a belief that there should be no conflict between the Conseil and the Council of State "simply will not wash", because, though the drafters might have "intended" two different "border guards", they only intended one "frontier". ${ }^{160}$ It may be, however, that the drafters intended not two different guards, but two different phenomena, only one of which was a guard. What the other was intended to be, other then quite French, is obscure. ${ }^{161}$

\section{B. Formal}

To some jurists the Conseil is unassailably judicial on generally textual grounds. Often proceeding by analogy, the assumptions remain largely untested, sometimes unstated. For instance, to BlancJouvan and Boulouis, the "fact" of finality, from Article 62 of the

cial body, warned that such a claim would risk creating a "hybrid and juridically monstrous being which would represent a fourth power of a nameless nature." C.E. 12 December 1969, 170 A.J. 103.

157. Supra n. 121 and accompanying text.

158. Debré's position, of course, must be qualified by the Constitution's subsequent history, especially the 1974 amendments increasing the Conseil's jurisdiction to include saisine by 60 senators or deputies. It might be that they tipped the scales. But in view of the post-1974 criticisms, it is clear that the critics do not believe so. See supra, n. 92 and accompanying text, and infra n. 171 and accompanying text.

159. Waline, "The Constitutional Council of the French Republic," $12 \mathrm{Am}$. J. Comp. L. 483, 487 (1963). This is effectively the position of Favoreu and Philip as well. See Favoreu \& Philip, supra n. 120.

160. Bermann, supra n. 122 at 484.

161. In other words, when Bermann says the Framers intended to create two sets of guards, the distinction between intent and result becomes confused. It is possible the drafters intended only one guard, but ironically created two, not realizing that people who walk back and forth at the border carrying guns are guards, no matter how they are chosen, what uniform they wear, what they are called, or even whose orders they obey. 
Constitution of 1958 , is conclusive whatever its actual scope and, therefore, Conseil decisions are definitionally "authoritative". ${ }^{162}$ To say that the Conseil's decisions are "authoritative", however, is to ignore the fact that both other French jurisdictions-the administrative and ordinary courts-have refused to be bound by a broad reading of the Conseil's jurisprudence (in the French sense of case law). ${ }^{163}$ And Jouvan and Boulouis read Article 62 with undue credence, for evidence of finality is solely derived from that textual provision.

Likewise, in the materiel phase of Waline's two-part test, ${ }^{104}$ the language the organ employs determines its juridicality (a court is one which employs "positive law" in its decisions). ${ }^{165}$ Substantially formalistic, this materiel phase assumes that simply labelling such language "legal" makes it so. ${ }^{166}$

At times, even the Conseil has adopted a formal or textual argument in characterizing itself. In its Decision of 16 January 1962,167 the Conseil refused to respond to the delegalization request by the Prime Minister to decide under Article 37, para. 2, whether a law relating to agricultural prices impermissibly attempted to address an area properly regulated only by executive decree. In two earlier decisions it had declared that agricultural prices were an executive responsibility, although it never formally delegalized the underlying agricultural law, that law never having been directly challenged. But those prior decisions had decided that the subject matter was of an executive, not legislative, character. So, in this decision it simply dismissed the request of the prime minister because it "must be regarded as without object", because the issue had already been decided. This was exclusively, in fact circularly, grounded on Article 62 which declares prior decisions of the Conseil binding. The Conseil held that such binding authority extended to the reasons as well as the results of its decisions. ${ }^{168}$

This case is generally viewed to hold that the Conseil considers itself to be a court since to dismiss a case as "without object" based

162. Blanc-Jouvan \& Boulouis, International Encyclopedia of Comparative Lav, Vol. I, National Reports, F-53 (1972).

163. See supra $n$. 40. The entire passage includes a functional reason, as well, for reaching a juridical conclusion:

A provision declared unconstitutional may be neither promulgated nor applied. Both from the formal or organic point of view and from that of the subject it deals with, it appears indisputable that the Constitutional Council is a real court.

Blanc-Jouvan \& Boulouis, supra n. 162 at F-53.

164. See, supra, text accompanying $\mathbf{n} .125$.

165. Waline, "Foreword" to Favoreu \& Philip, supra n. 120 at vi. See supra n. 125.

166. See supra, n. 125 and accompanying text.

167. Journel Officiel, 25 February 1962 at 1915.

168. Decision of 16 January 1962, Journel Officiel, 25 February 1962 at 1915. 
on previously decided issues is, within the civil law tradition, to assume a judicial posture. ${ }^{169}$ There is, however, no discussion within the decision, except the above reference to Article 62, which offers any jurisprudential support for the claim that the scope of its decisions extends to their underlying reasons.

\section{The Skeptics}

Bermann exemplifies the realist-skeptic when he somewhat quizzically questions whether "direct accessibility" has any essential connection with juridicality. ${ }^{170} \mathrm{He}$ is equally skeptical about the selection process as a determinant of judiciality. In true skeptical fashion, his comments imply that any choice of judicial characteristics is always arbitrary. ${ }^{171}$

Bermann's "border guard" metaphor ${ }^{172}$ and his conclusion that such shared jurisdiction is not inconsistent with a judicial nature, is the realist-skeptical articulation of the view that judicial activity lies along a continuum, is difficult to pin down, but is nevertheless not impossible to identify functionally. It is realistic and skeptical as well because it presciently recognized, well before it was fully realized, that Article 34 decisions had the potential of expanding as well as limiting legislative competence. ${ }^{173}$

Perhaps not surprisingly, there has been no critic until now ${ }^{174}$ who has advanced a critical-skeptical approach. However, the government itself has furnished sufficient evidence upon which to base such an approach. For instance, when the Conseil's decisions have been favorable, the government has urged that the Conseil is something other than a court. But when it has disagreed with the Conseil's decisions, the government, too, has claimed that the Conseil is a court whose decisions have only the narrow scope which, in its opinion, would-or, more accurately, should-be accorded a judicial body. ${ }^{175}$ Of course, for the government to adopt a purely prudential position is not surprising or, perhaps, even objectionable.

\section{The Avoidance Approach}

As long as the law/politics distinction remains important, the

169. The rejection of the Conseil's decision of 28 November 1973 , is in many ways a rejection of the breadth claimed here.

170. Bermann, supra n. 122 at 484 (1979).

171. Bermann, Comment II, 27 Am. J. Comp. L. 567, 584 (1979).

172. See supra, text accompanying $n .160$.

173. See Philip, "Le Developement du Controle de Constitutionnalite," 1983 R.D.P. 401, 498. See also, Conseil Constitutionnel, Decision 81-142 DC du 27 juillet 1982; Conseil Constitutionnel, Decision 82-143 DC du 30 juillet 1982.

174. See text, infra at 89-91.

175. See supra n. 120 at 167. 
jurisprudential dilemma presented by the Conseil is avoided only with a certain diffidence. Thus, a member of the Conseil itself has claimed that it hardly matters whether the Conseil is a court or not, the issue being entirely "academic" to him.176 One might just as well adopt Hauriou's terminology and characterize the nature of the Conseil as "parajudicial". ${ }^{177}$ Debré's position ${ }^{178}$ was that the Conseil is neither fish nor fowl. ${ }^{179}$ It is a "special institution", a "great and necessary innovation" dedicated to a special, even unique, task.

Even Waline, who ascribes to the Conseil a judicial character, could not avoid describing the Conseil's originally intended mission in a way differing subtantially from that of a court. The "principal reason" for the Conseil was to sanction legislative intrusions upon the executive domain. ${ }^{180}$ In other words, it was not explicitly conceived as a court of judicial review but more ambiguously as a sui generis organ of regulation. Whereas Waline, however, nevertheless concludes that it eventually evolved into a judicial body, Chatenet insists that this sui generis character, in fact, is what prevents the Conseil from being considered a juridical body; ${ }^{181}$ for much the same reasons, Juillard says:

The Constitutional Council is certainly not a judicial bodyso be it. We will prefer to say here that it amounts to an original body (organe original), acting in a judicial form. ${ }^{182}$

But this argument, like the label "parajudicial", merely avoids the problem. Similarly, when Neuborne nonchalantly announces that "the Conseil constitutionnel is a cross between a political arbiter and a court," 183 this should, in the context of his article, shock. His entire point is that certain practices of the Conseil could profitably be adopted by the Supreme Court, and it is not clear how such adoption could be accomplished if the two institutions are one, fish, one, fowl. ${ }^{184}$

The avoidance approach tends to hide behind unexamined terminology which labels the problem out of existence. These labels, however, though they describe the Conseil after a fashion, provide very little insight. It should not be surprising, though, that the

176. Goguel, "Le Conseil Constitutionnel," 1979 Rev. Dr. Pub. 5, 25.

177. See supra, text accompanying $n .99$.

178. See supra, text accompanying n. 121 and 158.

179. A vineophile student of mine comments that this is certainly no problem: a nice Bordeaux should do.

180. Weline, supra n. 159 at 485.

181. Chatenet, Le domaine de la loi et des reglements, Colloquium at the University of Aix-Marseille, at 134 (1977).

182. Juillard, supra n. 92 at $1703,1708$.

183. Neuborne, "Judicial Review and Separation of Powers in France and the United States," 57 N.Y.U.L. Rev. 363, 388 n. 91 (1982).

184. See, Rodgers \& Hammerstein, Showboat, "Can't Help Loving That Man of Mine," (". . fish gotta swim, birds gotta fly. . .") 
avoidance approach is essentially, and minimally, descriptive. Just as the formalist approach provides no analysis, the avoidance approach studiously refuses one. Coining a neologism provides a refuge from the controversy. It may be true that, instead of performing substantive constitutional review (whether judicial or otherwise) the Conseil was to regulate "the distribution of law-making power. . . "185 But to observe the Conseil's unique regulatory powers is to avoid understanding them, 'because this 'regulation' could be judicial or could be political; it is therefore not an answer."186 Luchaire observes that Juillard's solution ${ }^{187}$ of creating a new rubric, the "institutional", clouds rather than furthers the inquiry. To say that the "institutional" Conseil acts to create law while the "judicial" Austrian Supreme Court acts to destroy it is, to Luchaire, a semantic non sequitur. ${ }^{188}$

In addition, says Luchaire, Juillard ignores Article 37, which allows post-promulgation review, however limited, and the fact that Anglo-Saxon courts occasionally enjoin legislation prior to its application. Furthermore, Luchaire questions whether full constitutional review under Article 61 is materially different from Articles 37 and 41. The same question, he notes, can be asked about both: "does it bear upon matters relating to the legislative domain?"189

The avoidance position, of course, cannot be addressed jurisprudentially, since it rejects any jurisprudential argument. That rejection, however, is accomplished by adopting an implicit political position. ${ }^{190}$

Goguel's dismissal of "academic" questions is disingeuous. It inevitably asserts its own legitimacy while denying legitimacy to its critics. When Goguel claims that he "doesn't care" about the academic question, he wraps himself in a robe of apparent neutrality and implicitly claims a purely descriptive role: this is how it is, not how it should be, I take no academic (read, perhaps, "political") position.

\section{A POINT OF COMPARISON}

With the exception of those who adopt avoidance arguments, the critics all share one thing in common: an implicit reference to recognized judicial bodies, especially the U.S. Supreme Court, as judicial models. The comparison with the U.S. Supreme Court is pervasive, influential, and perhaps even decisive. A close examination

185. Beardsley, "Constitutional Review in France," 1975 S. Ct. Rev. 189, 225.

186. Luchaire, supra n. 9 at 17,31 .

187. See supra, text accompanying n. 103.

188. Luchaire, supra n. 79 at 34 .

189. Id. at $27,33-34$.

190. See text, supra at $57-60$. 
of these arguments must, therefore, start with an examination of this one common underlying premise. ${ }^{191}$

\section{Membership}

It is surprising that the membership issue has so dominated French jurists that they term it the Conseil's "original sin"192 because it is, of all the issues, the most easily challenged. Bermann simply noted the fact that many American judges are elected to fixed terms or appointed for political reasons, "yet this is not generally thought to make them any the less judges, or the courts they sit on any the less courts." 193

Political influence upon the Supreme Court membership, indeed, is so vividly demonstrated through both doctrine and history that the issue seems almost silly. Roosevelt's "court packing" plan starkly illuminated the political nature of the appointment process. ${ }^{194}$ His campaign to seize constitutional control from the "nine old men" was spearheaded by a movement largely initiated by a popular book of the same name. ${ }^{195}$ The attempt and ability of the Executive to "stack" the Supreme Court remains current and controversial, having re-entered national politics in the 1984 presidential debates, during which time it was claimed that the Republican presidential platform was committed to stacking the Court with anti-abortion members.

The membership problem addresses the absence of required qualifications for members of the Conseil, not just the political selection. But while U.S. Supreme Court judges have historically been lawyers, there is no constitutional requirement. Furthermore, the Court has held that legal training is not essential to a judicial-as opposed to Article III-position. The important issue, said the Court, is "the need for independent, neutral, and detached judgment, not . . . legal training."196

When Cappelletti and Cohen bemoan the Conseil's lack of

191. The comparison to the U.S. Supreme Court sometimes seems almost obsessive. It is the Court which most often-almost invariably-serves as the paradigm of the judicial organ. See for instance, Juillard, supra n. 92 at 1703, 1706 n. 4, 1707, and 1707 n. 8., as well as Luchaire, supra n. 79 at 17, 34, as well as, of course, Lambert, supra n. 14.

192. See supra $n .92$ and accompanying text.

193. Bermann, Comment II, 27 Am. J. Comp. L. 583, 584 (1979).

194. Murphy \& Pritchett, Courts, Judges, and Politics 376-379 (3rd ed. 1979) (citing Roosevelt speech of 9 March 1937); Senate Report No. 711, 75th Cong., 1st Sess., pp. 41-44).

195. Pearson \& Allen, The Nine Old Men (1936); see also, Pearson \& Allen, Nine Old Men at the Crossroads (1937). It is interesting to note that the age of the members of the Conseil has also been a continuing, though minor, concern to French authors who discuss it, unsurprisingly, with reference to our Supreme Court.

196. North v. Russell, 427 U.S. 328, 337, 96 S. Ct. 2709, 2713, 29 L.Ed.2d 534 (1976). 
scholarship, ${ }^{197}$ it should be recalled that the same criticism has occasionally been levelled against the justices of the Supreme Court, only a handful of whom have consistently received unanimously high grades. ${ }^{198}$

Finally, it is true, unlike members of the Conseil, Supreme Court justices are entitled to life tenure (although, as Bermann noted, many state court judges are not) and, indeed, life tenure is one of the two basic features that the Supreme Court has identified in distinguishing Article III judges from others (the other being protection from diminution in salary). ${ }^{199}$ However, many Supreme Court justices have decided not to serve so long. Ironically, one criticism of the court is that it is frequently top-heavy with elderly judges as a result of life tenure. ${ }^{200}$

Furthermore, Supreme Court justices are guaranteed life tenure only during "good behavior". There have been numerous attempts to impeach Supreme Court justices, some for no more than political reasons. ${ }^{201}$ There is nothing to indicate such political reasons could not constitute impeachable offenses. ${ }^{202}$

\section{Subject Matter}

At first blush, limiting the Conseil's subject matter to pre-promulgation review of legislation seems a serious defect since first, its limited review is not enriched by the facts of litigated cases and, second, it cannot serve as the "keeper of the nation's conscience". But though there is no such express limitation on the Supreme Court's subject matter, whether the Court effectively observes such a limitation is not so obvious.

There is reason to think, for example, that the Supreme Court subjects new practices to greater constitutional scrutiny than old and accords old practices some presumption of legitimacy. Justice

197. See supra, n. 97 and accompanying text.

198. Blaustein \& Mersky, "Rating Supreme Court Justices," 58 A.B.A.J. 1183 (1972).

199. Northern Pipeline Const. v. Marathon Pipe Line Co., 102 S. Ct. 2858 (1982).

200. Grossman, "Book Review," 1980 Wis. L. Rev. 429, 432.

201. The first attempt to impeach Justice Douglas was based on his issuance of a stay of execution in the Rosenberg case. 1953 Congressional Quarterly Almanac 311312. The second, 17 years later, was largely based on Douglas' authorship of articles which allegedly either favored leftist causes, appeared in disreputable journals, or both. 1970 Congressional Quarterly Almanac 1025-1027.

202. What, then, is an impeachable offense? The only answer is that an impeachable offense is whatever a majority of the House of Representatives considers it to be at a given moment in history. ... .

Representative Gerald Ford, 116 Cong. Rec. H. 3113 (daily ed. 15 April 1970). See Berger, Impeachment: The Constitutional Problems (1973). 
Rehnquist, for one, has expressly recognized this. ${ }^{203}$ But because such a notion might offend the theory of a supra-legislative norm justifying judicial review, the existence of such a subject-matter limitation has been denied-most notably, however, in the context of a case where such a limitation may well have been applied.204

This is not to imply that the Court acts nonjudicially when it proceeds judiciously. It is good sense for the Court to respect timehonored practices. To expect and require a court to exercise unlimited powers of review over well-established legislation and practices for it to qualify for judicial status reflects a romantic misreading of Supreme Court history.

Finally, actual practice belies the idea that the Court's supposed policy of unrestricted judicial review allows it to function as a moral policeman. Even Marbury v. Madison ${ }^{205}$ does not quite illustrate what the French critics claim, for the birth of American judicial review occurred in the court's own manger. It did not deny Congress any power to act; it rather declined to act itself, declaring its own jurisdiction narrower than what Congress had opined in the $1789 \mathrm{Ju}$ diciary Act.

More importantly, however, if the subject matter limitation under which the Conseil acts prevents it from being "the keeper of the nation's conscience", 206 by preventing judicial recognition of changing notions of morality, it is unlikely that, for instance, the passage of the 14 years between 1789 and 1803 in Marbury is good evidence that the Supreme Court is free to so act. This is not sufficiently long a passage to support the claim that the Court is adapting the law to changing standards of morality: for all practical purposes, federal legislation more than twenty years old is never invalidated. The average time period between enactment of federal legislation and declaration of unconstitutionality is nine and one-half years. Thus, legislation older than twenty years seems to enjoy a limit equally as protective as the post-promulgation limit under which the

\footnotetext{
203. While a particular course of executive conduct to which there was no opportunity for the legislative branch to effectively object cannot conclusively establish a constitutional authoritative judicial decision, a long continued practice on the part of the Executive, acquiesced in by the Congress, is itself some evidence of the existence of constitutional authority to support such a practice."
}

Rehnquist, "The Constitutional Issues-Administrative Position," in Falk(ed.), The

Vietnam War and International Law, Vol. III, The Widening Context 167 (1972), originally in 45 N.Y.U. L. Rev. 628 (1970).

204. A long standing but erroneous pattern of statutory interpretation may not be spared from the force of a constitutional mandate by reason of its longevity.

Lee v. Runge, 404 U.S. 887 (1971) (Douglas, J., dissenting).

205. Marbury v. Madison, 1 Cranch 137, 2 L.Ed. 60 (1803).

206. Supra n. 102 and accompanying and preceding text. 
Conseil operates. ${ }^{207}$ Unless one finds routine invalidation of federal legislation considerably older than that, old enough, in fact, to allow for changes in matters of morality, the notion that the Court can meaningfully and importantly function in this way is seriously suspect.

In the few other instances where the Court has accomplished major changes in old legislative settings, it has acted as a maker rather than a taker of the law..$^{208}$ In its expansive interpretation of the Civil Rights Act of 1866, it declared nothing unconstitutional. It instead found room in the statutory language for greater remedies. ${ }^{209}$ It would seem that to claim the Conseil is not a court on this basis is simply to misstate as well as misread history. To imply that the Supreme Court has carte blanche to overrule well-established legislation would be to turn the exception of Plessy v. Ferguson ${ }^{210}$ into a rule-and to ignore the fact that Plessy, of course, overruled court-made law, not legislation.

Note that it is not only the bar against post-promulgation review but also the very fact of pre-promulgation review that seems nonjudicial to some critics. The claim is essentially that review of legislation before it is applied is a legislative activity, and that, absent a real case or controversy, the richness of any potential argument is lost if an organ is allowed to "judge" legislation before the law has been applied.

But the Supreme Court has steadily increased its early review of legislation-functionally not much different than pre-promulgation review-to the extent that it allows injunctive relief against the very application of legislation. 211 When statutes are facially violative of important rights, the Court is willing to invalidate them broadly and quickly. ${ }^{212}$ Granted, most such review is limited to cases in which there is at least an allegation of bad faith or harassment. However, to the extent that there is something non-judicial about such review, the Conseil and the Supreme Court both suffer that defect. Even the Court has voiced concern over this. ${ }^{213}$

207. This figure was computed from a list of all federal legislation declared unconstitutional in whole or in part by the U.S. Supreme Court; Witt (ed.), Guide to the U.S. Supreme Court, 926-931 (1979). Naturally, this does not conclude state legislation which, perhaps, might be invalidated more readily by the Court after a considerably longer amount of time. But, then again, it might not. The important point is that these statistical data certainly do not support Waline's thesis and it would thus seem unwise to accept that thesis as gospel absent some countervailing empirical information.

208. See supra, text accompanying $n .106$.

209. Jones v. Alfred H. Mayer Co., 392 U.S. 409 (1968).

210. 163 U.S. 537 (1896); see Brown v. Board of Education, 347 U.S. 483 (1954).

211. Dombrowski v. Pfister, 380 U.S. 479 (1965).

212. Younger v. Harris, 401 U.S. 37 (1971); Watson v. Buck, 313 U.S. 387 (1941).

213. Younger v. Harris, 401 U.S. 37, 52-53 (1971). 


\section{Non-Contradictiousness}

The case or controversy doctrine supposedly assures contradictiousness; judicial intrusion into the legislative domain is prevented by maintaining the model of traditional common law litigation in Supreme Court practices. A case thus involves two litigants who share a private dispute. ${ }^{214}$

But Supreme Court practice, especially during this century, reveals a radical departure from this model. A substantial part of its caseload focuses on classic public issues such as voting rights, ${ }^{215} \mathrm{com}$ munity organization, ${ }^{216}$ and public morals. ${ }^{217}$ There are no parties in the classic sense. Instead of two, polar, individuals controlling litigation over private rights, the disputes have snowballed into massive multi-faceted conflicts over public rights in which dispute occurs as often over representation and tactics as over which party is advancing which claim. The abandonment of the "bipolar" litigation model has brought "greatly enlarged opportunities for use of constitutional litigation as an instrument of reform."218

In other words, the supposed American model used by French jurists to criticize the mechanism which brings disputes before the Conseil is inaccurate. The model of individuals coming to the Supreme Court unaffected by larger political issues and organizations either does not exist or occupies a minor place in Supreme Court litigation. It is substantially that phenomenon-the perversion of the traditional bipolar dispute through the presence, indeed influence, of additional parties, especially political groups-which critics of the Conseil claim prevents it from being a court.

To imagine, therefore, that the Supreme Court remains a pure model of classical two-party litigation is simply naive. The radical alteration of Supreme Court litigation, and the American judicial structure generally, has provoked profound questions over the nature of the judicial process. The substitution of "polycentric" for "bipolar" litigation models has caused American scholars to re-examine courts and juridicality and to conclude that the line between judicial and political adjudication is, at best, obscure. ${ }^{219}$ Critics of the Conseil who use American procedures as their model seem ignorant of that alteration and the discussion it has provoked.

One source of that alteration is the growing participation of

214. See Fuller, "The Forms and Limits of Adjudiciation," 92 Harv. $L$ Rev. 353 (1978).

215. Baker v. Carr, 369 U.S. 186 (1962).

216. Brown v. Board of Education, 347 U.S. 483 (1954).

217. Roe v. Wade, 410 U.S. 113 (1973).

218. Cox, "The Effect of the Search for Equality Upon Judicial Institutions," 1979

Wash U.L.Q. 795, 798.

219. Fuller, supra n. 214 at 353. 
amicus parties. "[A]micus curiae participation by private groups is now the norm rather than the exception."220 The effect of amicus participation is, of course, speculative, and would require extended empirical study. But common sense suggests that wealthy, sophisticated, and experienced, organizations would not expend their resources entering Supreme Court litigation unless they believed that such efforts were profitable-that is, that their presence affects the outcome.

Furthermore, criticisms which require of a court a "live" dispute in its purest form ignore the development of the declaratory judgment. The declaratory judgment's effect on the case or controversy requirement is disputed. Whether it is merely a procedural device which does not substantively change the jurisdiction of the Court or whether it is a substantive modification is debatable, at the very least. Willing $v$. Chicago Auditorium Ass'n. ${ }^{221}$ held that a declaratory judgment would violate the constitutional case or controversy doctrine. Nine years later, after the federal Declaratory Judgment Act was passed, this constitutional bar had suddenly vanished behind the claim that the new Act merely provided a new remedy.222 One American scholar attributed this simply to the fact that, in the interim, "[t]he Court changed its view."223 The massive alteration in constitutional litigation in the past few decades has been largely attributed to the declaratory judgment. ${ }^{224}$ To characterize the source of such a massive change as remedial rather than substantive surely damages that distinction.

Thus, far from departing from the Supreme Court model, the inclusion of political interests into the Conseil's practice actually approximates it. The simple presence of numerous cases before the Supreme Court of multiple parties, especially of distinct political interests, in violation of the traditional model, surely undermines the claim that the absence of individual litigants before the Conseil somehow fatally alters its nature.

\section{Procedural}

Broadly, the procedural objections amount to the claim that the Conseil's procedures are unstructured.225 The objections are directed at the lack of any formalized procedures which would con-

220. O'Connor \& Epstein, “Amicus Curiae Participation in U.S. Supreme Court Litigation," 16 L. \& Soc. Rev. 311, 318 (1981-2).

221. 277 U.S. 274, 48 S. Ct. 507 (1928).

222. Aetna Life Ins. Co. v. Haworth, 300 U.S. 227 (1937).

223. Wright, Law of Federal Courts 497 (3rd ed. 1976). But see Skelly Oil Co. v. Philips Petroleum Co., 339 U.S. 667 (1950).

224. Cox, supra n. 218 at $795,798$.

225. See Hamon, supra n. 111 at v. II. 
strain and direct the Conseil's activities, limit and define the kinds and scope of information it considers, and assure the public or parties a sense of participation. The Conseil's failure to provide an opportunity for hearings, to explain fully its decisions, to issue signed opinions and dissents, to have unlimited time in which to consider the issues, and its secrecy and non-oral procedures, are all part of a criticism basically directed towards the Conseil's unbridled discretion.

Objections to the secrecy of the Conseil's procedures, however, seem misplaced when compared to the Supreme Court, which has been accused of an excessive concern for secrecy. ${ }^{226}$ But, even if the Conseil had formal procedures similar to those of the U.S. Supreme Court, that would hardly serve to constrain it nor would it necessarily give a meaningful sense of participation-and certainly not one of control-to parties or the public generally. The Court is largely a creature of its own discretion. Even the case or controversy doctrine imposes little real constraint or direction ${ }^{227}$. Since the introduction of the "Brandeis brief", the Court has accepted certain information through the form of the written brief rather than in the form of a litigated record. ${ }^{228}$ The Court thus considers, in addition to the litigated facts, what are called "social facts". ${ }^{229}$ This is essentially no more than information added to the case, outside the matters which were tried below, which are consistent with the advocate's-and, ultimately, the Court's-perception of a "need for social progress".230

Further, the Court, rather than the record before it, defines the issues it will decide. By using such techniques as standing, ripeness, and the political question doctrine, it exercises an extraordinary amount of discretion and control over the questions that seem to arise. In fact, it has been praised for exercising those "passive virtues". 231 Furthermore, though theoretically it is only within its certiorari jurisdiction that the Court can exercise complete discretion over whether to hear a case, it has effectively exercised similar discretion over the cases within its mandatory appellate jurisdiction by qualifying the precedential effect of summary affirmance of those cases. ${ }^{232}$.

The summary affirmance itself is functionally no different than the Conseil's laconic unexplained decisions. No reasons or explana-

226. It has maintained a ritualized aura of secrecy which, when breached even slightly, lends credibility to irresponsible allegations.

Grossman, "Book Review," 1980 Wis. L. Rev. 429, 429.

227. See generally, supra, text accompanying n. 108-110.

228. Strum, Louis D. Brandeis-Justice for the People 114-131 (1984).

229. Id. at 122.

230. Urofsky, A Mind of One Piece 39 (1971).

231. Bickel, "Foreword: The Passive Virtues," 75 Harv. L. Rev. 40 (1961).

232. Edelman v. Jordan, 415 U.S. 651, 671 (1973). 
tions are provided. Because the affirmance is summary, there is no attribution of position to particular justices nor of divergence among them, and normally no dissents-since there is no opinion from which to dissent.

Though theoretically the Court is at least bound by the facts of each case, it can exercise an astonishing latitude in interpreting the facts to which they are supposedly bound. Litigants and scholars remark that the cases decided often bear little resemblance to the cases tried. In Gertz $v$. Robert Welch, Inc., ${ }^{233}$ the plaintiff was treated as "an individual who is neither a public official nor a public figure. .."234 But some commentators have noted the dramatic gap between the court's view of the facts and the reality that the plaintiff was a well-known activist, teacher, author, and public speaker. ${ }^{235}$ If the Court has such wide latitude in applying its own gloss to the facts, then the claim that the Court is bound by the record or, more importantly, that fair and open procedures allow litigants to control the direction of litigation, appears to be more of a heuristic statement than a factual description.

Perhaps most importantly, the common law doctrine of stare decisis within which the Court's procedures are supposed to operate and which, at least to the French, epitomize Supreme Court practice, are subject to wide judicial discretion. Chenot's observation that there are "no arguments and still less publicity of arguments"236 is only material if there is some firm body of principles and precedents over which to argue. Perhaps if stare decisis were as binding as theory claims, the opportunity to engage in a formal process complete with written briefs, public argument, signed opinions, and dissents, would be meaningful. But, in fact, the Court has insisted that, "[s]ince we deal with a constitutional question, we are less constrained by the principle of stare decisis than we are in other areas of the law."237 As the formal constraints on Supreme Court practices become more and more dubious, so too does the Conseil's procedural problem become more illusory than real.

\section{Jurisdiction}

The jurisdictional issue is probably equal to the membership issue in its rather obvious misapplication. To pretend that the U.S. Supreme Court constitutes a "court of last resort" for all other

233. 418 U.S. 323 (1974).

234. 418 U.S. 323,332 (1974).

235. Pember \& Teeter, "Privacy and the Press since Time, Inc. v. Hill," $50 \mathrm{Wash}$. L. Rev. 57 (1974); Anderson, "Libel and Press Self-Censorship," 53 Tex. L. Rev. 422, 448 (1975).

236. See supra n. 112.

237. Edelman v. Jordan, 415 U.S. 651,671 (1973). 
American jurisdictions is seriously to misstate American constitutional law. Not only do common law techniques allow lower courts either to avoid Supreme Court precedent altogether or to narrow it far beyond its intended scope, but the federal system as well as the multiple and, increasing, number of Federal Courts of Appeal severely restrict the impact of the Supreme Court as the final court. There are potentially 51 different positions on almost all constitutional questions, as long as none of them fall below minimal federal standards, which makes the French potential maximum of three seem almost attractive. Even within one State it is possible, due to federalism, for different rules to be applied to the same legal issue. While the New York Court of Appeals decided in People v. McCray, ${ }^{238}$ that racial discrimination in jury selection was not illegal, the Second Circuit has since decided otherwise in a collateral attack on the same underlying facts. ${ }^{239}$

While the McCray situation may be distinguished from that of the Conseil and its companion jurisdictions because the Supreme Court, unlike the Conseil, has the ultimate power to declare a uniform standard, such a distinction is misleading. First, as long as the Supreme Court exercises its "passive virtues" and fails to act, the result is the same. Secondly, however, to the extent a state court articulates a state constitutional standard more demanding than the federal one (a reverse McCray situation), the Supreme Court cannot require the state to adopt the federal rule, potentially leading to a patchwork of differing constitutional standards next to which the French situation pales. ${ }^{240}$

The Court's use of its "passive virtues"241 as a way of avoiding decision allows it purposely to tolerate divergence between the Circuits. Its use of summary affirmances has served to perpetuate a number of unresolved socially volatile issues, such as homosexual rights. Ironically, because the Supreme Court denied certiorari in McCray, it is possible that other Circuits might take that as an implied endorsement of the case, instead of following the Second Circuit. Or, then again, they might not.

238. 443 N.E.2d 915, 57 N.Y.2d 542 (1982), cert. denied, 103 S. Ct. 2438, 77 L.Ed.2d $1322(1983)$.

239. McCray v. Abrams, 750 F.2d 1113 (2d Cir. 1984).

240. For instance, many states have adopted, on state constitutional grounds, standards involving search and seizure, self-incrimination, double jeopardy, capital punishment, and a host of other issues, which conflict with and are more demanding than federal constitutional norms. In fact, as the Burger court has become more conservative, these state decisions have correspondingly increasingly and explicitly rejected the positions adopted by the Supreme Court. See "State Constitutional Law," The Nat'. L.J. 25-32 (Special Section, 12 March 1984); Wilkes, "The New Federalism in Criminal Procedure: State Court Evasion of the Burger Court," $62 \mathrm{Ky}$. L.J. 421 (1974).

241. See supra n. 230. 
Certainly, the existence of multiple state jurisdictions, of federal appeals courts, and even of common law techniques of analysis, does not alter the essence of the Supreme Court. But to the extent they transform the nature of the system from a unitary to an interactive one, the result is not too dissimilar from that of the Conseil, which has not had many instances of outright conflict with its companion jurisdictions.

\section{Institutional Design}

The U.S. Supreme Court appears to be one of three equal powers whose position, between the other two, is essentially neutral. The Constitution, including but not limited to Article III, does not appear textually to favor the President and disfavor Congress. But that is merely a formal observation. If the French system suffers from an institutional imbalance, the comparison with the Supreme Court must inquire into the Court's actual doctrines.

At first, Supreme Court practice as well as theory seems neutral with respect to the other two branches. To the extent the Court is solicitous of one branch-for instance through the political question doctrine-it is equally solicitous of the other branch. The political question doctrine does not distinguish between questions which are exclusively vested in the executive or legislative branch. To the extent the Court finds "a textually demonstrable constitutional commitment of the issue to a coordinate political department," it will simply refuse to decide the issue. ${ }^{242}$ While the doctrine is neutral on its face and is probably applied neutrally, some recent decisions in which the Court did not apply the doctrine but arguably might have done so actually seem to disfavor the President. ${ }^{243}$

But there seem to be discrete areas, most notably foreign affairs, in which the Court appears predisposed to favor the executive. This history and fabric of the Supreme Court is fairly defined by Marbury v. Madison and its progeny, which defines the Court as a limit on the legislature, not on the executive. Indeed, cases which involve war powers, espionage, and, more generally, foreign affairs, exhibit a marked tendency to allow the executive substantial latitude. ${ }^{244}$ This kind of selective bias in which the Court favors the ex-

242. Baker v. Carr, 369 U.S. 186, 217, 82 S. Ct. 691, 710, 7 L.Ed.2d 663 (1962).

243. See United States v. Nixon, 418 U.S. 683, 41 L.Ed.2d 1039, 94 S. Ct. 3090 (1974); Train v. City of New York, 420 U.S. 35, 43 L.Ed.2d 1, 95 S. Ct. 839 (1975).

244. United States v. Curtiss-Wright Export Corporation, 299 U.S. 304 (1936) (presidential powers in war-related foreign affairs); Ex parte Quirin, 317 U.S. 1 (1942) (executive and military powers in espionage case during wartime); Yamashita v. Styer, 327 U.S. 1 (1946) (executive war powers); Mora v. McNamara, 389 U.S. 934 (1967) (legality of Viet Nam War); Goldwater v. Carter, 444 U.S. 996, 62 L.Ed.2d 428, 100 S. Ct. 533 (1979) (President's unilateral abrogation of treaty); Snepp v. U.S., 444 U.S. 507, 100 S. Ct. 763 (1980) (executive powers in foreign intelligence matters). 
ecutive only in certain areas may reflect a kind of implicit judgment analogous to that more explicit judgment in the 1958 French Constitution's distribution of powers between the executive and legislature in Articles 34 and 37.

Thus, at least with regard to foreign affairs, war powers, espionage, and the like, the Supreme Court exhibits an institutional bias in favor of the executive much as, if not just as much as, the Conseil appears potentially biased against the Parlement. But, upon closer examination, there are instances in which the Conseil has been more willing to sanction the executive than has our Supreme Court. The possibility for Conseil hostility towards the executive has only become real since "l'alternance", 245 that is, the arrival of the Socialist government of Francois Mitterand in which both the National Assembly and the Administration are now ideologically opposed to the more conservative politics which, until now, produced a relatively conservative Conseil. The most remarkable example was the nationalization decision nullifying the indemnification provisions for Mitterand's plan to nationalize the French banking system. ${ }^{246}$ But at least equally important is a recent decision which effectively limited the executive and expanded the Article 34 legislative domain by expansively defining the central planning powers of the legislature to include what had hitherto been thought to be executive powers of "planification".247

The very notion that the institutional position of the Conseil is ineluctably tied to the administration, opposed to the legislature, is doubtful. As Bermann observed, the guard of one side of a frontier effectively is the guard of both. And, others have since observed the occurrence of this practice in the Conseil's decisions expanding the legislative domain. ${ }^{248}$

The legislative domain has been effectively expanded by the recent "price freeze" decision that Article 61 appeals cannot be brought to challenge alleged legislative intrusion into the administrative domain. ${ }^{249}$ This, in effect, means that unless the Govern-

245. Favoreu, "Le Conseil Constitutionnel et L'Alternance," 4 Rev. Française Science Politique (1984).

246. Conseil Constitutionnel, Decision 132 DC du 16 janvier 1982.

247. Conseil Constitutionnel, Decision 81-142 DC du 27 juillet 1982.

248. Before the appeals of parliamentarians directed against the intrusion of the legislator upon the regulatory domain, the Conseil has first adopted a more and more expansive conception of the domain of the law.

Philip, "Le Developpement du Controle de Constitutionnalite," 1983 R.D.P. 401, 498.

249. Conseil Constitutionnel, Decision 82-143 DC du 30 juillet 1982.

In this decision of potentially far-reaching implications, the Conseil declared that Art. 6.1 could not be used by deputies attacking a law establishing a system of fines against corporations which violate government price schedules. The deputies contended that such fines were contraventions which should be a matter of regulation, not of law. The Conseil held that only the Government could raise such a com- 
ment challenges such legislative action, Parlement is not subject to a challenge brought by the minority of 60 senators or deputies contemplated by the 1974 amendments to Article 61. Jurisprudentially, the decision is interesting because it effectively holds that legislative intrusion into the administrative domain is not seriously unconstitutional, or at least is not at the same level as violations of substantive constitutional provisions since review of this intrusion is now more difficult and inaccessible..$^{250}$ Most importantly, however, the decision parallels the American political question doctrine by leaving an executive-legislative dispute alone rather than resolving it.

Finally, the French view that the Conseil was never intended to be a judicial organ exercising judicial review over legislation is no different from the view held by some American critics. Those critics insist that Marbury v. Madison was erroneous and that Supreme Court judicial review represents a veritable judicial coup d'etat. ${ }^{251}$ Even some French critics view the ramifications of that case askance. ${ }^{252}$

\section{CONCLUSION}

It follows that the continuing debate over the Conseil's nature has three main sources: first, factual confusion; secondly, conceptual confusion; and thirdly, the political evolution and strategies of the French Republic.

The first source, assuming any reasonable amount of misinformation, does not seem especially problematical, though one cannot entirely ignore simple mistakes of fact. There is little doubt, as Favoreu has indicated, ${ }^{253}$ that the French are poorly informed (as are Americans) in matters of comparative law; misinformation explains much. But the conviction with which the debate over the Conseil's nature has raged tends to indicate that differences more fundamental than simple factual mistakes are its source.

The second source is more serious, challenging the very terminology of the debate and the law/politics distinction. The French use of this distinction as an essentialistic ideal-and the rigide separation of powers doctrine which it inspires-seems bound to produce insoluble problems because the distinction itself is fundamentally

plaint, holding effectively that delegalization could only be accomplished through Art. 37, para. 2, or Art. 41, and not through Art. 61. They relied upon the optional character of the delegalization process, thus refusing to transform a matter of constitutionally-grounded executive discretion into one of constitutional mandate.

250. See Philip supra n. 248 at 498.

251. Berger, Congress v. the Supreme Court (1969); Government by Judiciary (1977).

252. Lambert, supra n. 14.

253. See Favoreu, Rapport Général Introductif, Cours Constitutionnelles Européenes at Droits Fondamentaux 26-27 (1982). 
unsound. The debate and the various positions discussed in this article seem to show that. The concept of a court and of legal constraint as opposed to, and fundamentally distinct from, power in the form of executive discretion or legislative politics is philosophically and epistemologically suspect.

Both executive discretion and legislative politics are forms of unconstrained power, that is, power which is bounded only by momentary contingencies. The French essentialistically distinguish that power and those momentary contingencies from the legal constraints which define and bind judicial action. Therefore, the gulf, however wide, between a court and a political body-be it executive or legislative-is always, to the French, certain. That this is almost surely an illusion can be dramatized through deconstructive analysis.

Jacques Derrida has written that much philosophical idealization is founded upon an artificial positing, and, more importantly, a misunderstanding, of illusory first concepts. ${ }^{254}$ According to Derrida, those concepts are mistakenly deemed hierarchically superior and prior to other, therefore secondary and supposedly opposing, concepts. Other philosophers, such as Michael Ryan, have advanced the deconstructive analysis launch by Derrida, going beyond philosophical discourse to demonstrate the arbitrary and illusory nature of first principles used in political discourse, as well. ${ }^{255}$ That approach is useful in law as well as in politics. ${ }^{256}$

254. Derrida, Speech and Phenomena (1973); Derrida, Of Grammatology (1976); Derrida, "Limited Inc. abc," Glyph 2: Johns Hopkins Textual Studies 236 (1977).

255. Ryan, Marxism and Deconstruction (1982).

256. The application of deconstruction of this kind of problem merits an entire article, but the following paragraph, paraphrased from Ryan, illustrates it, with the substitution of the words law, constraint, and rules, for the word identity and the substitution of the words power and discretion for the word difference:

Through the strategy of opposition and prioritization, legal analysis represses everything that troubles its founding values. Indeed, its founding concepts-constraint, rule certainty, and others-come into being as the effacement and repression of such secondary terms as power and discretion. Deconstruction consists of upending the legal system of oppositions and priorities by showing how what legal analysis excludes as secondary and derivative in relation to an orginary concept of foundation-constraint say, in relation to discretion-is in fact more primordial and more general than the legal original. Discretion is not derived from constraint (nor power from law); rather, discretion makes constraint possible and, in so doing, makes impossible a rigorously pure system of constraint in the legal sense, one absolutely exempt from discretion. Once this initial reversal of a legal opposition is accomplished it is possible to prove that all concepts of foundation, ground, or origin must be similarly displaced. They are in fact points situated in relation to larger systems, chains, and movements, which Derrida often characterizes by using terms that in metaphysics name secondary and derivative elements, difference and writing being the most infamous. For instance, in order to operate, legal constrained power must presuppose discretionary, unconstrained power. Raw power and law relate to each other 
Deconstruction shows that the concept of a judicial body in opposition to a political one, or even of law in opposition to politics, is a false opposition, prioritizing the former over the latter and making it seem that they are distinctively different, whereas, in reality, and as a critical skeptic would understand, the latter are probably more general than the former. They, in fact, "relate to each other within each other". ${ }^{257}$

It is thus impossible for the critical-skeptic to define the Conseil as a court or as not a court in opposition to some other political organ just as it is impossible to define a legal domain in opposition to a political one. Any such attempted distinction quickly unravels as the debate over the Conseil demonstrates. The reason the French seem to fail at nailing down the Conseil is due to the fact that they are trying to nail it to itself; such a slippery object can never be immobilized and trying to do so can only lead to bruises.

All that remains, then, is to understand why this problem has plagued the French for the past twenty-five years, in contrast to our relative nonchalance over judicial review. In fact, the number of American legal critics who think the legitimacy of judicial review is an important question are no more numerous and influential than are the relatively few French critics who use the position of avoidance to dismiss the problem of the Conseil as unimportant.

The third source, then, is culturally and historically based. Clearly, it is the 1958 Constitution that created the problem-but I do not think it is simply the creation of the Conseil alone which precipitated the debate. It was, instead, the larger change that the Constitution produced which made a debate over law and politics central to French legal and political discourse. By horizontally diffusing power that had theretofore been arranged vertically (and thus had flowed more or less directly to the people), the new Constitution mandated a debate which would examine the security and responsiveness of democratic ideals. The sudden horizontal bureaucratization of the state, though historically tardy, required the development of additional legal constraints, or apparent constraints, to replace the lost vertical, and more direct, if only apparent, control. ${ }^{258}$ It also re-

within each other, mutually supplementing each other in a way that precludes a rigorous hierarchical and oppositional division between the two. Derrida claims that this movement of supplemental differentation is more primordial than any metaphysical opposition or grounding concept of rules, constraint, or law.

See id. at 10.

257. Id.

258. The observation sometimes made that the partition of competences effected by Arts. 34 and 37 merely constitutionalized the actual earlier practice of government through decree-laws does not change the claim made here. Decree-laws which effectively abdicated legislative responsibility in favor of executive discretion had, at 
quired a debate over their legitimacy.

Americans early on adopted judicial review as a way of dramatizing the distinction between law and politics and denying the fact of its illusory nature. Judicial review thus served as a counterweight to the anti-majoritarian impact of the combination of separation of powers doctrine and so-called democratic mechanisms of representation. The French, however, were never quite so far from pure democracy. The principle of legislative supremacy tended to shield them from the complete isolation that a strong executive within a fully developed system of separated powers would otherwise bring. A system of laws believed to control that more unresponsive state was necessary to the Americans, but a threat to the French.

The 1958 Constitution, however, changed all that. DeGaulle's successful assertion of executive power through that document represented the evolution of French democracy from the unstable, impotent, perhaps too democratic institution of the Third Republic into a super-bureaucratized industrial democracy. That evolution required the counterweight of some system which would represent a harbor of safety from the then far more unresponsive and thus threatening state. It was inevitable, though not necessarily intended, that in response to the development of the 1958 Constitution an entirely new and apparently constraining system of constitutional law would develop. The Conseil was simply the one logical source, but not the only one, ${ }^{259}$ of that law. The debate over its nature is symptomatic of that development and illustrates the centrality of

least, the illusion of ultimate legislative control. The shift from that abdication to constitutionally legitimate executive powers required, as a correlative, a corresponding apparent control, even if it is, in fact, just as illusory.

259. There seems to have developed, unsurprisingly perhaps, a reciprocal relationship between the Conseil, the Council of State, and perhaps ever the Cour de cassation in which each has influenced the constitutional jurisprudence of the other. Favoreu, "L'apport du Conseil constitutionnel au droit public," 1980 Pouvoirs $17 \mathrm{n}$. 13 ff.; 'L'influence de la jurisprudence du Conseil constitutionnel sur les differentes branches du droit," Itineraires a l'honneur de Leo Hamon 235 (1982), sometimes cited as Melanges Leo Hamon; "L'application direct et l'effet indirect des normes constitutionnelles," 1984 Rev. franćaise $d r$. admin. 174 n. 0. Compare Conseil constititionnel, Decision No. 71-44 D.C. of 16 July 1971, with Societe Eky, Conseil d'Etat 12 February 1960, J.C.P. 1960, II, 10629 bis note Vedel; see Odent, Contentieux administrative 1970-1971, at 166; Favoreu \& Philip, Les grandes decisions du conseil constitutionnel 245 (2d ed. 1979). Compare Conseil constitutionnel, Decision of 11 June 1981, with Jamart, Conseil d'Etat, 7 February 1936, S. 1937.3.113. See Luchaire \& Luchaire, Le droit de la decentralisation 94 (1983). Compare Conseil constitutionnel, Decision No. 74-54 D.C. of 15 January 1975, with Societe Jacques Vabre, C. Cass. Ch. mixte, 24 May 1975, 1975 R.D.P. 1335. Compare Conseil constitutionnel, Decision No. 77-87 D.C. of 23 November 1977, with Dame $R$. c/Association pour l'education populaire Ste. Marthe, Cass. Ass. plen., 19 May 1978, D. 1978, 541, consl. Schemelk, note Ardant. 
the law/politics distinction which is at the heart of all fully developed liberal democracies.

It was in the environment of this growing but inevitable body of overarching rules that the Conseil was born. Inevitably it would fashion the rules-or, at least, a part of them-that the bureaucratized state required. In those circumstances, the articulation of constitutional rules was a necessary correlative of the horizontal dispersion of power-necessary to convince the French that, in place of the more immediate vertical legislative responsiveness, there was at least some constraint, any constraint. In this context, I do not personally think that it mattered that the Conseil was, theoretically, only a limit upon the legislature. The creation, or massive expansion, of a body of constitutional law was far more important than its particular content. It is interesting, nonetheless, to note the growing real limits the Conseil has managed to impose upon the executive despite the Conseil's theoretical design. ${ }^{260}$

The Conseil's function looks, therefore, very much like what an American thinks of as a court, despite differences in detail. Whether it is called a court may not matter. But the function it performs was essential, and remains essential, to maintain the illusion that the state is responsive to its citizens, once real democratic responsiveness, or at least its appearance, is lost to state bureaucracy.

260. See supra, text accompanying n. 245-247. 